\title{
Adam Korolczuk
}

\section{Amerykańska polityka wobec rynku pracy a weterani pokolenia 9/11}

\begin{abstract}
Streszczenie
Jeszcze kilka lat temu zatrudnienie weterana było kojarzone w Stanach Zjednoczonych z działalnością charytatywną. Obecnie zarówno administracja publiczna, jak i wiele firm sektora prywatnego wyrażają chęć pomocy byłym żołnierzom. Wygaszanie obecności Amerykanów w Afganistanie, połączone z cięciami wydatków na obronę, spowoduje, że $\mathrm{z}$ sił zbrojnych będzie musiało odejść w ciągu najbliższych pięciu lat około miliona żołnierzy. Większość z nich zasili rynek pracy, jednak znaczna część, zwłaszcza najmłodszych weteranów wojen w Iraku i Afganistanie, pozostanie bezrobotna. Sprawy weteranów są niezwykle istotne zarówno dla prezydenta Stanów Zjednoczonych, Kongresu, jak i całego społeczeństwa amerykańskiego, gdyż związane są z ekonomiczno-społeczną stroną funkcjonowania państwa. Natomiast błędne wyobrażenie na temat byłych żołnierzy uniemożliwia wykorzystanie ich potencjału oraz nabytych w wojsku umiejętności i nie przekłada się w żaden sposób na ekonomię państwa. Taka sytuacja jest frustrująca, ponieważ weterani potrafią być bardzo dobrymi pracownikami, posiadają wiele zalet, które są pożądane wśród zatrudniających, m.in. umiejętności przywódcze, współdziałanie, lojalność, inicjatywę.
\end{abstract}

Słowa kluczowe: amerykańscy weterani, wojna w Afganistanie, rynek pracy, bezrobocie

\section{American policy towards labor market and post-9/11 veterans}

\begin{abstract}
A few years ago, veteran employment was associated in the United States with the charity. Today both public administration and many private companies are willing to assist former soldiers. Within the next five years, about one million soldiers will have to leave the armed forces because of the planned partial withdrawal of the U.S. troops from Afghanistan and defense cuts. Most of them will find employment, however, a significant percentage, especially the young veterans of the Iraq and Afghanistan wars will remain
\end{abstract}


unemployed. Veterans affairs are crucial both for the President of the United States, the Congress and the whole American society, as they are related to the economic and social aspects of the state functioning. On the other hand, misconception about ex-combatants prevents the use of their potential and skills acquired in the military, and is not reflected in any way on the economy of the state. This situation is frustrating because veterans can be very good workers having many qualities that are desirable among employers, such as leadership skills, cooperation, loyalty and initiative.

Keywords: American veterans, the war in Afghanistan, the labor market, unemployment

Stany Zjednoczone rozpoczęły operację wojskową w Afganistanie 7 października 2001 r. w odpowiedzi na ataki terrorystyczne z 11 września 2001 r. na wieże World Trade Center i Pentagon ${ }^{1}$. Bezpośrednią przyczyną wybuchu wojny w Afganistanie była odmowa wydania Osamy bin Ladena, podejrzanego o zorganizowanie zamachów. Siły zbrojne Stanów Zjednoczonych wkroczyły w nowy etap walki z terroryzmem. Tym samym rozpoczął się nowy rozdział w prowadzeniu działań wojennych przez amerykańskich żołnierzy. Czas ten definiowany jest jako Gulf War Era II'. Weterani służby z tego okresu to mężczyźni i kobiety służby czynnej, Gwardii Narodowej oraz Rezerwy, którzy pełnili służbę w wojsku od września $2001 \mathrm{r}$.

Mimo że system wsparcia weteranów powracających z misji w Iraku i Afganistanie jest rozbudowany, nadal istnieją niedociągnięcia związane z zapewnieniem im płynnego i bezproblemowego przejścia na cywilny rynek pracy. Składa się na to wiele czynników, takich jak wykształcenie, stopień niepełnosprawności, relacje z zatrudniającymi czy zaangażowanie w poszukiwaniu pracy. Celem artykułu jest przedstawienie sytuacji amerykańskich weteranów wojen w Iraku i Afganistanie na rynku pracy, próba analizy ich zatrudnienia w sektorze publicznym, wskaźników bezrobocia, przyczyn tego zjawiska oraz perspektyw na najbliższe lata.

1 K. Michałek, Amerykańskie stulecie. Historia Stanów Zjednoczonych Ameryki 1900-2001, MADA, Warszawa 2004, s. 771-773.

2 Na potrzeby danych statystycznych zostały wypracowane przez Departament Spraw Weteranów oraz Departament Pracy Stanów Zjednoczonych określenia odnoszące się do chronologicznych przedziałów czasowych, w których amerykańscy żołnierze pełnili służbę, niezależnie od miejsca. Gulf War Era II datuje się od września 2001 r. do chwili obecnej, Gulf War Era I od sierpnia 1990 do sierpnia 2001 r., Vietnam Era od sierpnia 1964 do kwietnia 1975 r., Korean War od lipca 1950 do stycznia 1955 r., World War II od grudnia 1941 do grudnia 1946 r., World War I od kwietnia 1917 do listopada 1918 r., Other service periods lub Peacetime określa służbę żołnierzy we wszystkich innych przedziałach czasowych. Weterani zostali sklasyfikowani tylko na podstawie ich jednego (ostatniego) wskazanego wyżej okresu służby. Weterani Gulf War Era II to wszyscy żołnierze, którzy pełnili służbę w Afganistanie od października 2001 r., w Iraku od marca 2003 r. lub w obu tych lokalizacjach. 


\section{Weterani pokolenia 9/11}

Nie są prowadzone oficjalne odrębne statystyki bezrobocia wśród weteranów wojny w Afganistanie lub Iraku, wynika to głównie z tego, że żołnierze w okresie 2001-2014 kilkukrotnie pełnili służbę zarówno w Iraku, jak i Afganistanie. W literaturze przedmiotu oraz dla porządku chronologicznego są zatem określani jako weterani II fazy Wojny w Zatoce (Gulf War Era II Veterans), weterani po 11 września (post 9/11 Veterans) lub weterani pokolenia $9 / 11$. Materiały wykorzystane w niniejszym artykule pochodzą w większości ze źródeł anglojęzycznych, w znacznej mierze z dostępnych źródeł internetowych. W języku polskim dotychczas ukazały się opracowania jedynie o fragmentarycznym charakterze w przedmiotowym temacie. W związku z dużą liczbą nazw własnych i terminów obcych konieczne było wprowadzenie podwójnego zapisu - tłumaczenie na początku, a w nawiasie oryginału angielskiego oraz skrótu, jeśli taki funkcjonuje.

Amerykanie analizują rynek pracy według wielu kryteriów, jednakże w swoich analizach dodatkowo precyzyjnie mierzą, jak wygląda na rynku pracy sytuacja weteranów. Nie bez znaczenia jest amerykańska definicja terminu „weteran”. Została ona określona w dziale 38, \$101(2) Kodeksu Stanów Zjednoczonych (United States Code) oraz w dziale $38 \$ 3.12$ (a) Kodeksu Regulacji Federalnych (Code of Federal Regulations) i jest odmienna od ujęcia polskiego ${ }^{3}$. Zgodnie z zapisami federalnymi, weteranem można nazwać każdego byłego żołnierza, który niezależnie od miejsca pełnił czynną służbę w wybranym rodzaju sił zbrojnych Stanów Zjednoczonych i nie został zwolniony ze służby dyscyplinarnie ${ }^{4}$. Status weterana przysługuje również żołnierzom, którzy ze względów zdrowotnych, w wyniku wypadku lub kontuzji, byli zmuszeni zakończyć służbę.

Moment zakończenia amerykańskich działań w Afganistanie stał się początkiem zobowiązań wobec weteranów, również na rynku pracy. Okres wojny związany był nie tylko z ogromnymi kosztami. Uwagę najważniejszych osób w państwie zwrócił wskaźnik poziomu bezrobocia, jakie dotyka byłych żołnierzy, głównie tych, którzy uczestniczyli w działaniach wojennych od 2001 r. w Afganistanie oraz od 2003 r. w Iraku. Kwestia ta okazała się szczególnie istotna, nie tylko dla zdrowia fizycznego i psychicznego uczestników wojny, ich relacji z otoczeniem, wypełnienia potrzeb

3 Zgodnie z art. 2 Ustawy z dnia 19 sierpnia 2011 r. o weteranach działań poza granicami państwa, weteran to żołnierz lub funkcjonariusz, który brał udział w działaniach poza granicami państwa, w ramach misji pokojowej lub stabilizacyjnej, przez okres nie krótszy niż 60 dni.

4 S.D. Szymendera, Who is a „Veteran”? - Basic Eligibility for Veterans' Benefits, Congressional Research Service Report, August 19, 2015, s. 1, https://www.fas.org/sgp/crs/misc/R42324.pdf, dostęp 24.02.2014. 
finansowych dnia codziennego, ale także ze względu na zagospodarowanie potencjału, umiejętności i kwalifikacji weteranów w nowej, cywilnej rzeczywistości ${ }^{5}$. Byli żołnierze postrzegani są dwuwymiarowo, z jednej strony jako bohaterowie, żandarmi współczesnego świata, uczestnicy ciężkich walk przeciwko globalnemu terroryzmowi, natomiast $\mathrm{z}$ drugiej jako osoby o wąskiej specjalizacji nabytej w wojsku i nie w pełni dostosowane do realiów cywilnego rynku pracy. $\mathrm{W}$ amerykańskiej prasie cyklicznie ukazują się felietony opisujące umiejętności weteranów, ich zalety i wady dla potencjalnego zatrudniającego. Medialne dyskusje oraz wyjątkowy wysyp publikacji o tej tematyce pojawia się zazwyczaj w przeddzień obchodzonego 11 listopada w Stanach Zjednoczonych Dnia Weterana.

Mając na uwadze ryzyko, jakie weterani ponieśli, uczestnicząc w walkach w Iraku czy Afganistanie, trudno uwierzyć, że mogliby mieć problemy z wejściem na rynek pracy. Składa się jednak na to wiele różnych czynników. Wojna w Afganistanie była inna od wszystkich poprzednich, zarówno pod względem znaczącego udziału Gwardii Narodowej i Rezerwy, jak i rodzaju prowadzonych działań, czasu trwania misji, środowiska walki, częstotliwości rotacji, rodzaju urazów oraz skutków dla samych weteranów, ich rodzin i społeczeństwa. Operacja pod kryptonimem „Trwała Wolność" oraz dalsza działalność wojsk amerykańskich w Afganistanie były najdłuższą misją prowadzoną przez Stany Zjednoczone od czasu wojny w Wietnamie. Jest to również pierwsza wojna (obok operacji „Iracka Wolnośc”7), w której udział wzięli tylko ochotnicy. Większość z nich doświadczyła kilku misji. W 2012 r. 37 tys. amerykańskich żołnierzy uczestniczyło w co najmniej pięciu zmianach, a 400 tys. w co najmniej trzech ${ }^{8}$. Miało to swoje skutki nie tylko społeczne, ale także ekonomiczne. Większość mężczyzn i kobiet powracających z afgańskiej misji poradziło sobie z doświadczeniami i trudami wojny. Część jednak miała i ma nadal poważne problemy z przystosowaniem się do rzeczywistości. Okrucieństwo wojny, stres, depresja, agresja, długa rozłąka oraz nałogi odcisnęły swoje piętno na życiu rodzinnym i funkcjonowaniu w społeczeństwie, w tym na rynku pracy.

5 N. Berglass, M.C. Harrell, Well After Service. Veteran Reintegration and American Communities, Center for a New American Security, April 2012, s. 31, http://www.cnas.org/files/documents/publications/CNAS_WellAfterService_BerglassHarrell.pdf, dostęp 18.07.2015.

6 Operation Enduring Freedom - trwająca od 2001 r. operacja obejmowała działania militarne Stanów Zjednoczonych wymierzone w Al-Kaidę oraz wspierających ją talibów. Do przeprowadzenia operacji przeznaczono łącznie 60 tys. żołnierzy amerykańskich, z czego połowa stacjonowała w rejonie Zatoki Perskiej.

7 Operation Iraqi Freedom, zob. Irak. Dylematy amerykańskiej interwencji, red. W. Dzielski, W. Michnik, Księgarnia Akademicka, Kraków 2007.

8 Ch. Adams, Millions went to war in Iraq, Afghanistan, leaving many with lifelong scars, http://www. mcclatchydc.com/news/nation-world/national/article24746680.html, dostęp 24.09.2015. 
W ostatnich latach amerykańskich weteranów wojen w Iraku i Afganistanie witała gospodarka będąca w okresie stagnacji. Bezrobocie w Stanach Zjednoczonych zaczęło gwałtownie rosnąć pod koniec 2008 r., gdy rozpoczął się kryzys finansowy. Narodowe Biuro Badań Ekonomicznych ${ }^{9}$ (National Bureau of Economic Research) określiło początek recesji na grudzień 2007 r., natomiast sytuacja na rynku pracy pogarszała się przez cały 2008 rok $^{10}$. W październiku 2009 r. stopa bezrobocia sięgnęła nienotowanego od lat poziomu 10\%. To oznaczało niemal 15,4 mln bezrobotnych Amerykanów ${ }^{11}$. Obecna sytuacja na amerykańskim rynku pracy wskazuje na to, że stosunkowo trudno jest znaleźć pracę właśnie młodym ludziom, niezależnie od tego, czy byli w wojsku, czy nie ${ }^{12}$. Stopa bezrobocia wśród weteranów ostatnich wojen w Iraku i Afganistanie jest po części efektem sytuacji demograficznej. Są to weterani młodzi i mniej wykształceni niż ogół społeczeństwa - jest to więc skorelowane z bezrobociem w tej grupie. Dane dotyczące zatrudnienia wśród weteranów gromadzone są co miesiąc przez Biuro Statystyki Pracy (Bureau of Labor Statistics) - jednostkę wchodzącą w skład Departamentu Pracy Stanów Zjednoczonych (U.S. Department of Labor). Badaniom ankietowym (Current Population Survey) poddawanych jest ok. 60 tys. gospodarstw domowych. W 2014 r. w Stanach Zjednoczonych było 3,2 mln weteranów, mających za sobą epizod służby wojskowej w okresie od września 2001 do grudnia 2014 r., z czego $20 \%$ stanowiły kobiety ${ }^{13}$. Prawie połowa weteranów pokolenia 9/11 była w wieku 25-34 lata. Stopa bezrobocia wśród mężczyzn, którzy służyli w służbie czynnej w armii Stanów Zjednoczonych od września 2001 r. wyniosła w 2014 r. 6,9\%. Wśród kobiet weteranów w tej samej grupie bezrobocie wyniosło $8,5 \%{ }^{14}$.

\footnotetext{
${ }^{9}$ National Bureau of Economic Research (NBER) to największa, założona w 1920 r. ekonomiczna organizacja badawcza w Stanach Zjednoczonych. NBER definiuje recesję jako spadek aktywności ekonomicznej trwający dłużej niż kilka miesięcy, widoczny w realnym PKB, realnym dochodzie, zatrudnieniu, produkcji przemysłowej i sprzedaży detalicznej, http://www.nber.org/cycles.html, dostęp 1.09.2015. Data rozpoczęcia recesji wskazywana jest na podstawie ustalenia początku spadku PKB, aż do pierwszego znaczącego odbicia. Czas między tymi dwoma momentami nazywany jest recesją. Okres wzrostu definiowany jest analogicznie. http://www.nber.org/cycles/recessions.html, dostęp 1.09.2015.

10 S.F. Hipple, The Labor Market in 2009: Recession Drags ON, "Monthly Labor Review" 2010, Vol. 133, No. 3, s. 3, http://www.bls.gov/opub/mlr/2010/03/art1full.pdf, dostęp 1.09.2015.

${ }_{11}$ Bezrobocie w USA najniższe od pięciu lat. W listopadzie spadło do 7 proc., http://m.wyborcza.biz/biznes/1,106501,15088744, Bezrobocie_w_USA_najnizsze_od_pieciu_lat_W_listopadzie.html?piano_t $=1$, dostęp 29.12.2014.

12 J. Hobson, Unemployment falls to 7.7\%, 236,000 jobs added, http://www.marketplace.org/topics/economy/unemployment-falls-77-236000-jobs-added, dostęp 5.12.2014.

${ }_{13}$ Dla porównania, kobiety weterani II wojny światowej, wojny w Korei oraz Wietnamie łącznie stanowią $4 \%$ wszystkich weteranów.

14 Employment Situation of Veterans Summary 2014, Bureau of Labor Statistics, U.S. Department of Labor, http://www.bls.gov/news.release/vet.nr0.htm, dostęp 22.09.2015.
} 


\section{Bezrobocie wśród weteranów}

Międzynarodowa Organizacja Pracy (International Labor Organization) definiuje bezrobocie jako zjawisko, w którym osoby zdolne do pracy, poszukujące i deklarujące chęć jej podjęcia, nie znajdują rzeczywistego zatrudnienia ${ }^{15}$. W 2014 r. 21,2 mln mężczyzn i kobiet (9\% całkowitej populacji w wieku 18 lat i więcej) posiadało status weterana. $Z$ tej liczby $10,2 \mathrm{mln}$ było zatrudnionych, natomiast 573 tys. stanowili bezrobotni. Pozostali $(10,5 \mathrm{mln})$ znajdowali się poza siłą roboczą ${ }^{16}$. Weterani, którzy pełnili służbę podczas II wojny światowej, wojnie w Korei i Wietnamie, stanowią prawie połowę wszystkich weteranów w Stanach Zjednoczonych ${ }^{17}$. Bezrobocie w Stanach Zjednoczonych jest obok ogromnego długu publicznego, rosnących nierówności społecznych oraz niewydolnego systemu politycznego jednym z największych wyzwań tego światowego mocarstwa. Brak zatrudnienia jest dotkliwy dla wszystkich grup społecznych, ze względu na słabo rozbudowany system zabezpieczeń socjalnych ${ }^{18}$. Stopa bezrobocia, czyli stosunek liczby bezrobotnych do wielkości zasobów siły roboczej, wynosiła w latach 2001-2014 od 4,6\% do 9,6\%. Szczegółowe dane przedstawia tabela 1 .

Tabela 1. Stopa bezrobocia w Stanach Zjednoczonych w latach 2001-2014 (w \%)

\begin{tabular}{|c|c|c|c|c|}
\hline Lata & Całkowita populacja & Wszyscy weterani & Pokolenie 9/11 & Cywile \\
\hline 2001 & 4,7 & b.d. & b.d. & b.d. \\
\hline 2002 & 5,8 & b.d. & b.d. & b.d. \\
\hline 2003 & 6,0 & b.d. & b.d. & b.d. \\
\hline 2004 & 5,5 & b.d. & b.d. & b.d. \\
\hline 2005 & 5,1 & b.d. & b.d. & b.d. \\
\hline 2006 & 4,6 & 3,8 & 6,4 & b.d. \\
\hline 2007 & 4,6 & 3,8 & 6,1 & 4,4 \\
\hline 2008 & 5,8 & 4,6 & 7,3 & 5,6 \\
\hline 2009 & 9,3 & 8,1 & 10,2 & 9,1 \\
\hline
\end{tabular}

15 International Labor Organization (ILO) Resolutions Concerning Economically Active Population, Employment, Unemployment and Underemployment Adopted by the $13^{\text {th }}$ International Conference of Labor Statisticians, October 1982, par. 10, http://www.ilo.org/public/english/bureau/stat/download/res/ecacpop.pdf, dostęp 23.02.2015.

16 Veteran unemployment rate decreases to 5.3 percent in 2014, http://www.bls.gov/opub/ted/2015/veteran-unemployment-decreases-in-2014.htm, dostęp 6.08.2015.

17 Employment Situation of Veterans Summary, Bureau of Labor Statistics, U.S. Department of Labor, http://www.bls.gov/news.release/vet.nr0.htm, dostęp 16.09.2015.

${ }_{18}$ M. Wałkuski, Wałkowanie Ameryki, Wydawnictwo Helion, Gliwice 2012, s. 300. 


\begin{tabular}{|c|c|c|c|c|}
\hline Lata & Całkowita populacja & Wszyscy weterani & Pokolenie 9/11 & Cywile \\
\hline 2010 & 9,6 & 8,7 & 11,5 & 9,4 \\
\hline 2011 & 8,9 & 8,3 & 12,1 & 8,7 \\
\hline 2012 & 8,1 & 7,0 & 9,9 & 7,9 \\
\hline 2013 & 7,4 & 6,6 & 9,0 & 7,2 \\
\hline 2014 & 6,2 & 5,3 & 7,2 & 6,0 \\
\hline
\end{tabular}

Źródło: opracowanie własne na podstawie danych Biura Statystyki Pracy (Departament Pracy), Bureau of Labor Statistics, U.S. Department of Labor, http://www.bls.gov/home.htm

Niskie bezrobocie, zwłaszcza do momentu recesji, można wytłumaczyć stosunkowo dużym zatrudnieniem w niskopłatnych segmentach gospodarki, ale także sposobem liczenia bezrobocia ${ }^{19}$. Do zatrudnionych zalicza się osoby wykonujące pracę w niepełnym wymiarze godzin (involuntary part-timers). Takich osób w $2014 \mathrm{r}$. było w USA $7,3 \mathrm{mln}^{20}$. Natomiast ze statystyk bezrobotnych wyłącza się wszystkich tych, którzy zrezygnowali z aktywnego poszukiwania pracy (discouraged workers). Osoby te nie są zaliczane do zasobów siły roboczej, w latach 2001-2014 było to ponad $1,5 \mathrm{mln}$ osób $^{21}$. W ten sposób zmniejszona została stopa bezrobocia. Biuro Statystyki Pracy definiuje osoby zatrudnione i bezrobotne. Do zatrudnionych należą ci, którzy $\mathrm{w}$ tygodniu przepracowali za wynagrodzeniem co najmniej jedną godzinę lub pomagali (bez wynagrodzenia) w rodzinnej działalności gospodarczej przez co najmniej 15 godzin w tygodniu. Metodologia liczenia bezrobocia w Stanach Zjednoczonych opiera się na prowadzonych każdego miesiąca przez Biuro Statystyki Pracy (Bureau of Labor Statistics) badaniach ankietowych na 60 tys. wylosowanych gospodarstw domowych, przekłada się to na ok. 110 tys. osób miesięcznie ${ }^{22}$. Każdego miesiąca $25 \%$ wylosowanych gospodarstw zastępowane jest przez nową grupę, zatem jedno gospodarstwo domowe badane jest przez okres czterech miesięcy. Później następuje ośmiomiesięczna przerwa w ankietowaniu konkretnego gospodarstwa, następnie jest ono badane ponownie przez cztery miesiące, po czym ostatecznie zostaje usunięte z wylosowanej próby ${ }^{23}$.

\footnotetext{
19 S.G. Kozłowski, Ameryka wspótczesna. Pejzaż polityczny i społeczno-gospodarczy, Wydawnictwa UMSC, Lublin 2008, s. 334.

20 P. Gillespie, Part-time jobs put millions in poverty or close to it, http://money.cnn.com/2014/ 11/20/news/economy/america-part-time-jobs-poverty/, dostęp 22.09.2015.

${ }^{21}$ M. Boesler, What The Unemployment And Labor Force Participation Rates Would Be If All Of The Discouraged Workers Came Back, http://www.businessinsider.com/unemployment-rate-if-discouragedworkers-came-back-2014-1, dostęp 22.09.2015.

${ }_{22}$ How the Government Measures Unemployment, Current Population Survey (CPS), June 2014, s. 2, Bureau of Labor Statistics, U.S. Department of Labor. http://www.bls.gov/cps/cps_htgm.pdf, dostęp 22.09.2015.

${ }^{23}$ S.G. Kozłowski, op.cit., s. 335.
} 
Tabela 2. Wskaźnik bezrobocia wśród amerykańskich weteranów w wieku powyżej 18 lat w 2014 r. pod względem etnicznym, okresu służby oraz płci (w \%)

\begin{tabular}{|l|c|c|c|c|c|}
\hline \multicolumn{1}{|c|}{ Wskaźnik } & $\begin{array}{c}\text { Wojna w Zatoce } \\
\text { (II faza) } \\
2001-2014\end{array}$ & $\begin{array}{c}\text { Wojna w Zatoce } \\
\text { (I faza) } \\
\text { 1990-2001 }\end{array}$ & $\begin{array}{c}\text { II wojna światowa, } \\
\text { wojna w Korei, } \\
\text { wojna w Wietnamie }\end{array}$ & Pozostałe konflikty & Cywile \\
\hline Mężczyźni & 6,9 & 4,0 & 5,0 & 5,3 & 6,2 \\
\hline Kobiety & 8,5 & 5,2 & 5,4 & 4,2 & 5,9 \\
\hline Biali Amerykanie & 6,4 & 4,0 & 4,6 & 4,3 & 5,1 \\
\hline Czarni Amerykanie & 9,5 & 4,2 & 8,2 & 9,6 & 11,3 \\
\hline Azjaci & 7,4 & 2,8 & 5,3 & 2,3 & 4,9 \\
\hline Latynosi & 7,6 & 5,0 & 6,1 & 5,9 & 7,2 \\
\hline
\end{tabular}

Źródło: Veteran unemployment rate decreases to 5,3 percent in 2014, Bureau of Labor Statistics, U.S. Department of Labor, http://www.bls.gov/opub/ted/2015/veteran-unemployment-decreases-in-2014.htm

Pomimo czternastoletniego udziału amerykańskich żołnierzy w konfliktach w Afganistanie i Iraku pojawiło się zaskakująco mało badań społecznych poświęconych ponownej integracji ekonomicznej weteranów ze społeczeństwem ${ }^{24}$. Dane Biura Statystyki Pracy jednoznacznie wskazują, że weterani ostatnich wojen, zwłaszcza młodzi, doświadczają wyższego poziomu bezrobocia niż ich cywilni rówieśnicy. W 2014 r. bezrobotnych było $7,2 \%$ weteranów pokolenia $9 / 11^{25}$ i prawie $16,2 \%$ weteranów w wieku 18-24 lata ${ }^{26}$. Obraz ten może jednak ulec pogorszeniu w związku ze złą sytuacją finansową Departamentu Obrony Stanów Zjednoczonych. Amerykanie planują przeprowadzenie redukcji wojsk lądowych o 40 tys. żołnierzy do $2017 \mathrm{r}^{27}$. Zmniejszona o 20 tys. żołnierzy będzie także Gwardia Narodowa oraz o 10 tys. Rezerwa (Army Reserve) ${ }^{28}$. Przymusowe zwolnienia są nieuniknione ${ }^{29}$, a tym samym

${ }^{24}$ M. Kleykamp, Unemployment, Earnings and Enrollment among Post 9/11 Veterans, "Social Science Research" 2013, No. 42, s. 836, http://www.sciencedirect.com/science/article/pii/S0049089X13000021, dostęp 17.06.2015.

${ }^{25}$ Employment status of persons 18 years and over by veteran status, period of service, sex, race, and Hispanic or Latino ethnicity, 2014 annual averages, Bureau of Labor Statistics, U.S. Department of Labor, http://www.bls.gov/news.release/vet.t01.htm, dostęp 19.09.2015.

26 Employment status of persons 18 years and over by veteran status, age and period of service, 2014 annual averages, Bureau of Labor Statistics, U.S. Department of Labor, http://www.bls.gov/news.release/vet. t02A.htm, dostęp 19.09.2015.

27 J. Palowski, Zwolnienia żolnierzy w US Army. Szczegóły planu cięć, http://www.defence24.pl/238133, zwolnienia-zolnierzy-w-us-army-szczegoly-planu-ciec, dostęp 21.06.2015.

28 T. Wróbel, Znikająca armia, „Polska Zbrojna” 2015, nr 8, s. 90.

${ }^{29}$ Od 2012 r. redukcja dotknęła już 80 tys. żołnierzy. Plany zmniejszenia docelowej liczebności czynnej armii Stanów Zjednoczonych poniżej obecnego poziomu 490 tys. żołnierzy powstały w świetle sekwestracji, czyli automatycznych cięć wydatków federalnych, wdrożonych zgodnie z Budget Control Act w 2013 r. Przedstawiciele amerykańskich wojsk lądowych podkreślają, że utrzymanie automatycznych cięć w pełnej wysokości może zmusić do ograniczenia liczebności wojska do 420 tys. żołnierzy, ze względu na konieczność wygospodarowania środków finansowych na modernizację i utrzymanie gotowości bojowej. Kolejne 
mogą potęgować reintegrację zawodową weteranów rozpoczynających poszukiwanie pracy na rynku cywilnym. Weterani współczesnych wojen znacznie częściej niż ich rówieśnicy z poprzednich pokoleń zawierają związki małżeńskie i zakładają rodziny ${ }^{30}$. W konfliktach w Iraku i Afganistanie wzięło również udział więcej kobiet ${ }^{31}$, zatem skuteczność i efekt ponownego przejścia do pracy w cywilu przekłada się także na życie rodzinne, współmałżonków oraz dzieci weteranów.

Tabela 3. Wskaźnik zatrudnienia i bezrobocia wśród amerykańskich weteranów w wieku powyżej 18 lat, w 2014 r., pod względem płci oraz rasy (w tys.)

\begin{tabular}{|l|c|c|c|c|c|}
\hline \multicolumn{1}{|c|}{ Wskaźnik } & $\begin{array}{c}\text { Wszyscy } \\
\text { weterani (w tys.) }\end{array}$ & $\begin{array}{c}\text { Sita robocza } \\
\text { (\% populacji) }\end{array}$ & $\begin{array}{c}\text { Zatrudnieni } \\
(\% \text { populacji) }\end{array}$ & $\begin{array}{c}\text { Bezrobotni } \\
\text { (\% sity roboczej) }\end{array}$ & Poza sitą roboczą \\
\hline Wszyscy weterani & 3,185 & $\begin{array}{c}2,535 \\
(79,6)\end{array}$ & $\begin{array}{c}2,353 \\
(73,9)\end{array}$ & $\begin{array}{c}182 \\
(7,2)\end{array}$ & 649 \\
\hline Mężczyźni & 2,549 & $\begin{array}{c}2,096 \\
(82,2)\end{array}$ & $\begin{array}{c}1,952 \\
(76,6)\end{array}$ & $\begin{array}{c}144 \\
(6,9)\end{array}$ & 453 \\
\hline Kobiety & 635 & $\begin{array}{c}439 \\
(69,2)\end{array}$ & $\begin{array}{c}402 \\
(63,3)\end{array}$ & $\begin{array}{c}37 \\
(8,5)\end{array}$ & 196 \\
\hline Biali Amerykanie & 2,449 & $\begin{array}{c}1,977 \\
(80,7)\end{array}$ & $\begin{array}{c}1,849 \\
(75,5)\end{array}$ & $\begin{array}{c}127 \\
(6,4)\end{array}$ & 472 \\
\hline Afroamerykanie & 490 & $\begin{array}{c}366 \\
(74,6)\end{array}$ & $\begin{array}{c}331 \\
(67,5)\end{array}$ & $\begin{array}{c}35 \\
(9,5)\end{array}$ & 124 \\
\hline Azjaci & 90 & $\begin{array}{c}74 \\
(82,7)\end{array}$ & $\begin{array}{c}69 \\
(76,6)\end{array}$ & $\begin{array}{c}5 \\
(7,4)\end{array}$ & 16 \\
\hline Latynosi & \multirow{2}{*}{423} & $\begin{array}{c}331 \\
(78,2)\end{array}$ & $\begin{array}{c}306 \\
(72,3)\end{array}$ & $\begin{array}{c}25 \\
(7,6)\end{array}$ & 92 \\
\hline
\end{tabular}

Źródło: opracowanie własne na podstawie Employment Situation of Veterans 2014, USDL-15-0426, Bureau of Labor Statistics, U.S. Department of Labor, http://www.bls.gov/news.release/vet.t01.htm

Na podstawie badań przeprowadzonych przez Biuro Statystyki Pracy w $2014 \mathrm{r}$. wskaźnik bezrobocia wszystkich weteranów wynosił 5,3\% i był nieco niższy od tego z 2013 r. (6,6\%). Wśród mężczyzn bezrobocie wynosiło 5,2\% natomiast wśród

zwolnienia (15 tys. żołnierzy) planowane są w 2016r., następne (15 tys. żołnierzy) w 2017 r., natomiast w 2018 r. z mundurem rozstanie się 10 tys. żołnierzy. Łącznie, w latach 2012-2018 odejdzie do cywila 120 tys. żołnierzy ( $21 \%$ będących w służbie czynnej). Pracę straci także 17 tys. pracowników cywilnych wojska. Tym samym siły zbrojne Stanów Zjednoczonych będą miały liczebność najmniejszą od $1940 \mathrm{r}$. Szacuje się, że w ciągu czteroletniej redukcji kadr Departament Obrony zaoszczędzi około 7 mld USD.

${ }^{30}$ D. Segal, Recruiting for Uncle Sam: Citizenship and Military Manpower Policy, University Press of Kansas, Lawrence 1989, s. 13.

31 Według danych Biura Statystyk Pracy w 2014 r. było 635 tys. kobiet weteranów Wojny w Zatoce fazy II (2001-2014), Employment status of the civilian noninstitutional population 18 years and over by veteran status, period of service, and sex, 2013-2014, annual averages. Bureau of Labor Statistics, U.S. Department of Labor, http://www.bls.gov/news.release/vet.a.htm, dostęp 21.06.2015. 
kobiet 6,0\%. Zbliżony wskaźnik panował wśród ludności cywilnej (6,2\% mężczyzn i 5,9\% kobiet) ${ }^{32}$. Prawie połowa weteranów Gulf War Era II jest w wieku 25-34 lata.

Tabela 4. Wskaźnik zatrudnienia i bezrobocia wśród amerykańskich weteranów i ludności cywilnej w wieku powyżej 18 lat, w latach 2013-2014, pod względem okresu służby oraz płci (w tys.)

\begin{tabular}{|c|c|c|c|c|c|c|}
\hline \multirow[b]{2}{*}{$\begin{array}{c}\text { Status } \\
\text { weteranów }\end{array}$} & \multicolumn{3}{|c|}{2013} & \multicolumn{3}{|c|}{2014} \\
\hline & $\begin{array}{c}\text { Wszyscy } \\
\text { weterani } \\
\text { (\% populacji) }\end{array}$ & $\begin{array}{c}\text { Mężczyźni } \\
\text { (\% populacji) }\end{array}$ & $\begin{array}{c}\text { Kobiety } \\
\text { (\% populacji) }\end{array}$ & $\begin{array}{c}\text { Weterani } \\
\text { (\% populacji) }\end{array}$ & $\begin{array}{l}\text { Mężczyźni } \\
\text { (\% populacji) }\end{array}$ & $\begin{array}{c}\text { Kobiety } \\
\text { (\% populacji) }\end{array}$ \\
\hline \multicolumn{7}{|c|}{ WETERANI WSZYSTKICH WOJEN } \\
\hline Liczba weteranów & 21,397 & 19,173 & 2,225 & 21,229 & 19,023 & 2,206 \\
\hline Siła robocza & $\begin{array}{c}10,975 \\
(51,3)\end{array}$ & $\begin{array}{l}9,565 \\
(49,9)\end{array}$ & $\begin{array}{l}1,410 \\
(63,4)\end{array}$ & $\begin{array}{c}10,744 \\
(50,6)\end{array}$ & $\begin{array}{l}9,358 \\
(49,2)\end{array}$ & $\begin{array}{l}1,386 \\
(62,8)\end{array}$ \\
\hline Zatrudnieni & $\begin{array}{c}10,253 \\
(47,9)\end{array}$ & $\begin{array}{l}8,940 \\
(46,6)\end{array}$ & $\begin{array}{l}1,313 \\
(59,0)\end{array}$ & $\begin{array}{c}10,171 \\
(47,9)\end{array}$ & $\begin{array}{l}8,868 \\
(46,6)\end{array}$ & $\begin{array}{l}1,303 \\
(59,0)\end{array}$ \\
\hline Bezrobotni & $\begin{array}{l}722 \\
(6,6)\end{array}$ & $\begin{array}{l}625 \\
(6,5)\end{array}$ & $\begin{array}{c}97 \\
(6,9)\end{array}$ & $\begin{array}{l}573 \\
(5,3)\end{array}$ & $\begin{array}{c}490 \\
(5,2)\end{array}$ & $\begin{array}{c}83 \\
(6,0)\end{array}$ \\
\hline Poza siłą roboczą & 10,422 & 9,608 & 815 & 10,485 & 9,664 & 821 \\
\hline \multicolumn{7}{|c|}{ WETERANI POKOLENIA 9/11 (2001-2014) } \\
\hline Liczba weteranów & 2,837 & 2,259 & 579 & 3,185 & 2,549 & 635 \\
\hline Siła robocza & $\begin{array}{l}2,286 \\
(80,6)\end{array}$ & $\begin{array}{l}1,879 \\
(83,2)\end{array}$ & $\begin{array}{c}407 \\
(70,3)\end{array}$ & $\begin{array}{l}2,535 \\
(79,6)\end{array}$ & $\begin{array}{l}2,096 \\
(82,2)\end{array}$ & $\begin{array}{c}439 \\
(69,2)\end{array}$ \\
\hline Zatrudnieni & $\begin{array}{l}2,081 \\
(73,3)\end{array}$ & $\begin{array}{l}1,713 \\
(75,8)\end{array}$ & $\begin{array}{c}368 \\
(63,6)\end{array}$ & $\begin{array}{l}2,353 \\
(73,9)\end{array}$ & $\begin{array}{l}1,952 \\
(76,6)\end{array}$ & $\begin{array}{c}402 \\
(63,3)\end{array}$ \\
\hline Bezrobotni & $\begin{array}{l}205 \\
(9,0)\end{array}$ & $\begin{array}{l}166 \\
(8,8)\end{array}$ & $\begin{array}{c}39 \\
(9,6)\end{array}$ & $\begin{array}{c}182 \\
(7,2)\end{array}$ & $\begin{array}{l}144 \\
(6,9)\end{array}$ & $\begin{array}{c}37 \\
(8,5)\end{array}$ \\
\hline Poza sitą roboczą & 552 & 380 & 172 & 649 & 453 & 196 \\
\hline \multicolumn{7}{|c|}{ CYWILE } \\
\hline Liczba cywilów & 215,339 & 94,850 & 120,489 & 217,820 & 96,213 & 121,607 \\
\hline Siła robocza & $\begin{array}{l}142,391 \\
(66,1 \%)\end{array}$ & $\begin{array}{l}72,114 \\
(76,0 \%)\end{array}$ & $\begin{array}{l}70,277 \\
(58,3 \%)\end{array}$ & $\begin{array}{l}143,207 \\
(65,7 \%)\end{array}$ & $\begin{array}{l}72,565 \\
(75,4 \%)\end{array}$ & $\begin{array}{l}70,641 \\
(58,1 \%)\end{array}$ \\
\hline Zatrudnieni & $\begin{array}{l}132,189 \\
(61,4 \%)\end{array}$ & $\begin{array}{c}66,712 \\
(70,3 \%)\end{array}$ & $\begin{array}{l}65,477 \\
(54,3 \%)\end{array}$ & $\begin{array}{l}134,589 \\
(61,8 \%)\end{array}$ & $\begin{array}{l}68,095 \\
(70,8 \%)\end{array}$ & $\begin{array}{l}66,494 \\
(54,7 \%)\end{array}$ \\
\hline Bezrobotni & $\begin{array}{l}10,202 \\
(7,2 \%)\end{array}$ & $\begin{array}{l}5,402 \\
(7,5 \%)\end{array}$ & $\begin{array}{l}4,800 \\
(6,8 \%)\end{array}$ & $\begin{array}{l}8,618 \\
(6,0 \%)\end{array}$ & $\begin{array}{l}4,470 \\
(6,2 \%)\end{array}$ & $\begin{array}{l}4,148 \\
(5,9 \%)\end{array}$ \\
\hline Poza siłą roboczą & 72,948 & 22,736 & 50,212 & 74,613 & 23,647 & 50,966 \\
\hline
\end{tabular}

Źródło: opracowanie własne na podstawie Employment Situation of Veterans 2014, USDL-15-0426, Bureau of Labor Statistics, U.S. Department of Labor, http://www.bls.gov/news.release/vet.a.htm

${ }^{32}$ Veteran unemployment rate decreases to 5.3 percent in 2014, Bureau of Labor Statistics, U.S. Department of Labor, http://www.bls.gov/opub/ted/2015/veteran-unemployment-decreases-in-2014.htm, dostęp 6.08.2015. 
Okres przejściowy, w którym żołnierze opuszczali siły zbrojne i zasilali cywilny rynek pracy, istniał od zawsze. Dlatego organizacje rządowe i społeczne poprzez kursy, szkolenia i współpracę z przedsiębiorcami starają się skrócić ten czas, ponieważ zdają sobie sprawę, jaką wartość weterani mogą wnieść na rynek pracy. Ekonomia Stanów Zjednoczonych nadal odczuwa wielką recesję lat 2007-2009, zatem minie trochę czasu zanim całkowity wskaźnik powróci do sytuacji sprzed tego okresu, kiedy bezrobocie wynosiło 5\% lub mniej. Bezrobocie wśród młodych osób jest wyższe, jednak nie świadczy to o tym, że jest to grupa w jakimś sensie gorsza. Stopa bezrobocia nie jest miarą dokładną, zlicza jedynie osoby aktywnie poszukujące pracy. Niemniej, najmłodsi weterani mają mniejsze szanse na zatrudnienie niż ich rówieśnicy, którzy w wojsku nigdy nie byli. Jednym z powodów takiego stanu rzeczy jest niepełnosprawność wśród weteranów ostatnich wojen. Wśród weteranów Pokolenia 9/11 (2001-2014), prawie trzech na dziesięciu (928tys.) stanowili niepełnosprawni. Ponadto raport Departamentu Pracy podaje, że w 2014 r. 29\% (928 tys.) weteranów pokolenia 9/11 dotkniętych było różnym stopniem niepełnosprawności wynikającej z faktu służby wojskowej, stanowi to $16 \%$ weteranów wszystkich wojen ${ }^{33}$.

Tabela 5. Wskaźnik bezrobocia wśród amerykańskich niepełnosprawnych weteranów (kobiet i mężczyzn) w 2014 r.

\begin{tabular}{|l|c|c|c|c|}
\hline $\begin{array}{c}\text { Procent uszczerbku } \\
\text { na zdrowiu }\end{array}$ & $\begin{array}{c}\text { Weterani } \\
\text { wszystkich wojen }\end{array}$ & $\begin{array}{c}\text { Bezrobotni } \\
\text { (\% sity roboczej) }\end{array}$ & Pokolenie 9/11 & $\begin{array}{c}\text { Bezrobotni } \\
\text { (\% sity roboczej) }\end{array}$ \\
\hline \multicolumn{5}{|c|}{ NIEPEŁNOSPRAWNOŚĆ ZWIAZZANA ZE SŁUŻBA } \\
\hline Populacja & 3,435 & 5,9 & 928 & 9,1 \\
\hline$<30$ & 25 & 4,5 & 17 & 10,7 \\
\hline $30-50$ & 23 & 5,0 & 11 & 5,2 \\
\hline $60<$ & 33 & 8,5 & 29 & 11,4 \\
\hline \multicolumn{5}{|c|}{ NIEPEŁNOSPRAWNOŚĆ NIEZWIAZZANA ZE SŁUŻBA } \\
\hline Populacja & 13,692 & 5,9 & 1,493 & 7,8 \\
\hline
\end{tabular}

Źródło: opracowanie własne na podstawie Employment Situation of Veterans 2014, USDL-15-0426, Bureau of Labor Statistics, U.S. Department of Labor, http://www.bls.gov/news.release/vet.t07.htm

\section{Zatrudnienie w sektorze publicznym}

Sprawy weteranów są niezwykle istotne zarówno dla prezydenta Stanów Zjednoczonych, Kongresu, jak i całego społeczeństwa amerykańskiego, gdyż związane

${ }^{33}$ Employment Situation of Veterans - 2014, Bureau of Labor Statistics, U.S. Department of Labor, 2015, s. 3 http://www.bls.gov/news.release/pdf/vet.pdf, dostęp 2.09.2015. 
są z ekonomiczno-społeczną stroną funkcjonowania państwa. Wielu zgadza się ze stwierdzeniem, że zatrudnianie weteranów to przede wszystkim przejaw patrioty$\mathrm{zmu}^{34}$. Z tego też względu jest to jeden $\mathrm{z}$ głównych tematów poruszanych podczas corocznego orędzia o stanie państwa (State of the Union). W listopadzie $2011 \mathrm{r}$. prezydent Stanów Zjednoczonych Barack Obama podczas swojego przemówienia z okazji Dnia Weterana przyznał, że „żaden weteran, który walczył za Amerykę nie powinien zmagać się z poszukiwaniem pracy, gdy powróci do Ojczyzny" ${ }^{35}$. Dwa miesiące później, 24 stycznia 2012 r., naczelny dowódca sił zbrojnych porównał weteranów powracających z Iraku i Afganistanu do weteranów II wojny światowej. W przemówieniu wskazał, że to właśnie weterani II wojny światowej zbudowali najsilniejszą ekonomię i klasę średnią, jaką kiedykolwiek widział świat ${ }^{36}$. Natomiast w 2013 r. prezydent Obama wzbudził aplauz słuchaczy, zapowiadając stopniowe wycofywanie z Afganistanu 34 tys. żołnierzy w $2014 \mathrm{r}^{37}$. Tym samym oznaczało to opuszczenie przez tysiące żołnierzy szeregów armii i aktywne poszukiwanie nowej profesji na rynku pracy. Jak się okazało, nie będzie to łatwe zadanie. Roczny raport rządowego biura badającego statystyki rynku pracy dotyczący sytuacji weteranów pokazał, że poziom bezrobocia wśród weteranów pokolenia 9/11 w wieku 25-34 lata wynosił 7,8\% w czwartym kwartale 2014 r. Bezrobocie wśród osób cywilnych w tym samym przedziale wiekowym wynosiło $6,5 \%{ }^{38}$. Największą grupę bezrobotnych stanowią weterani z Afganistanu i Iraku w wieku 18-24 lata - 16,2\%.

Wydaje się, że weterani pokolenia 9/11 mają szansę dogonić rówieśników, tak jak zrobili to niegdyś ich poprzednicy - weterani walk II wojny światowej, wojny w Korei i Wietnamie. Jak się okazało, kilkadziesiąt lat zajęło im stopniowe obniżanie stopy bezrobocia wśród swojego pokolenia w stosunku do reszty populacji. Obecna ekonomia Stanów Zjednoczonych wymaga jednak znacznie szybszego wejścia weteranów na cywilny rynek pracy. Współcześni weterani są w mniej korzystnej sytuacji niż ich poprzednicy, jeżeli chodzi o kwestię zatrudnienia i szanse na utrzymanie się na rynku pracy. Służba w Gwardii Narodowej lub Rezerwie dodatkowo

${ }^{34}$ K. Drummond, Veterans Make Valuable Employees, So Why Aren't More Getting Hired?, http:// www.forbes.com/sites/katiedrummond/2012/06/12/cnas-veterans-jobs/, dostęp 29.01.2015.

35 R. Gorman, Saluting America's heroes: Obama joins sailors at end of emotional Veterans Day to watch college basketball spectacle on aircraft carrier that buried Bin Laden at sea, http://www.dailymail. co.uk/news/article-2060426/Obama-marks-Veterans-Day-basketball-spectacle-aircraft-carrier-buriedBin-Laden-sea.html, dostęp 20.07.2015.

${ }^{36}$ G. Wyler, Here's The Full Text Of Tonight's State Of The Union Address, http://www.businessinsider. com/full-text-barack-obama-state-of-the-union-2012-1, dostęp 12.01.2014.

${ }^{37}$ E. Lindsey, 2013 State of the Union Address: An annotated transcript, http://www.marketplace. org/topics/economy/2013-state-union-address-annotated-transcript, dostęp 11.02.2014.

38 Employment status of persons 18 years and over by veteran status, age, and period of service, 2014 annual averages, Bureau of Labor Statistics, U.S. Department of Labor, http://www.bls.gov/news.release/vet. t02A.htm, dostęp 19.08.2015. 
zakłóca funkcjonowanie młodych weteranów na cywilnym rynku pracy. Żołnierze tych formacji mogą zostać powołani na ćwiczenia lub misję w dowolnym momencie i na wybrany okres. Może się okazać, że po powrocie do domu z rocznej misji w Afganistanie weteran po trzech miesiącach od momentu podjęcia pracy zostanie rozkazem skierowany na kilkutygodniowe ćwiczenia. Niewielu zatrudniających potrafi prowadzić własną działalność w takim systemie i zaakceptować takiego pracownika. Zgodnie z Kodeksem Stanów Zjednoczonych ${ }^{39}$ dyskryminacja wobec żołnierzy Gwardii Narodowej i Rezerwy jest zabroniona i niezgodna z prawem. Takie działanie narusza federalne prawo pracy (Uniformed Services Employment and Reemployment Rights Act) ${ }^{40}$ oraz ustawę o osobach niepełnosprawnych (Americans with Disabilities $A c t)^{41}$, które zakazują takich praktyk. Osoba zatrudniająca jest natomiast zobowiązana do zachowania miejsca pracy w czasie powołania rezerwisty. Mimo to szefowie firm stosują wiele zabiegów, aby obejść prawo. Wielu zdecydowanie bardziej woli zatrudnić osobę poszukującą pracy, która definitywnie zakończyła służbę wojskową lub nie jest $\mathrm{z}$ wojskiem związana. Z inicjatywą wyszedł Departament Obrony Stanów Zjednoczonych, tworząc program wsparcia Yellow Ribbon ${ }^{42}$ przeznaczony dla żołnierzy Gwardii i Rezerwy oraz ich rodzin. Dzięki licznym przedsięwzięciom promocyjnym, edukacyjnym i społecznym prawa i przywileje weteranów są należycie respektowane.

Co roku ok. 250 tys. amerykańskich żołnierzy odchodzi z wojska. Większość korzysta z programów oferowanych przez Pentagon, stworzonych z myślą o ułatwieniu przejścia do życia cywilnego. To z kolei prowadzi zazwyczaj w jednym kierunku - do zatrudnienia w administracji publicznej. Prawie połowę pracowników federalnych stanowią weterani wojen w Iraku i Afganistanie, w większości niepełnosprawni. Stanowi to pewien fenomen, jeżeli weźmiemy pod uwagę uczestników innych wojen. Weterani od zawsze brani byli pod uwagę jako kadry zasilające stanowiska rządowe, niektórzy twierdzą, że wręcz byli faworyzowani w konkursach na dane stanowisko. Wyjątkowy wzrost liczby weteranów w służbie cywilnej widoczny był

${ }^{39}$ Kodeks Stanów Zjednoczonych (United States Code) to uporządkowany zbiór prawa federalnego, dział 38 poświęcony jest zasiłkom dla weteranów (Veteran's Benefits), rozdział 43 (Uniformed Services Employment and Re-Employment Rights Act), sekcje 4301-4335 omawiają szczegółowo kwestie prawne regulujące zatrudnianie służb mundurowych, http://www.dol.gov/vets/usc/vpl/usc38.htm, dostęp 5.09.2015.

${ }^{40}$ U.S. Department of Labor, USERRA Advisor, http://www.dol.gov/elaws/vets/userra/userra.asp, dostęp 18.09.2015.

${ }^{41}$ U.S. Equal Employment Opportunity Commission, Veterans and the Americans with Disabilities Act (ADA): A Guide for Employers, http://www.eeoc.gov/eeoc/publications/ada_veterans_employers. cfm, dostęp 18.09.2015.

${ }^{42}$ Yellow Ribbon Reintegration Program, http://www.yellowribbon.mil/yrrp/, dostęp 20.09.2015. 
po II wojnie światowej oraz po wojnie w Wietnamie ${ }^{43}$. Najwyższy wskaźnik widoczny jest jednak od 2009 r., kiedy prezydent Obama zdecydował o zwiększeniu liczby weteranów w administracji. 9 listopada 2009 r. prezydent Stanów Zjednoczonych podpisał rozporządzenie wykonawcze nr 13518 (Employment of Veterans in the Federal Government $)^{44}$. Amerykanie szanują weteranów, a jednocześnie nie ufają federalnym biurokratom, paradoks polega na tym, że coraz częściej są to te same osoby. W 2014 r. zatrudnionych w administracji publicznej zostało ok. 180 tys. osób, z tej liczby 59 tys. stanowili weterani $(33,2 \%)$. Rok wcześniej było to $31 \%$. Liczba wszystkich pracowników federalnych spadła z 2015 tys. w 2013 r. do 1990 tys. w roku następnym, weteranów natomiast wzrosła: z 607 tys. w 2013 r. do 612 tys. w 2014 r. Jednakże, mimo szerokiego katalogu preferencji, weterani bardzo szybko porzucają pracę w administracji publicznej. Jak podaje Biuro Zarządzania Personelem (Office of Personnel Management) jedynie 62\% weteranów piastuje stanowiska przez minimum dwa lata. Weterani wyprzedzają pod tym względem inne grupy pracowników administracji $(82 \%)^{45}$. Jak się okazuje, biurokracja oraz rodzaj pracy, jaką wykonują weterani, nie do końca zgodna jest $\mathrm{z}$ ich kwalifikacjami i oczekiwaniami.

Wiele stanów USA prowadzi własne programy federalne, mające na celu udzielanie pomocy weteranom kończącym służbę w armii. Nowe inicjatywy dotyczące płynnego przejścia weteranów na cywilny rynek pracy pojawiają się zazwyczaj przy okazji Dnia Weterana, który w Stanach Zjednoczonych przypada 11 listopada. Pomoc weteranom w ramach programów rekonwersyjnych odbywa się na szczeblu regionalnym i ogólnokrajowym. Rządowe przedsięwzięcia, takie jak Troops to Truckers ${ }^{46}$,

${ }^{43}$ Veterans: What next?, http://www.economist.com/news/united-states/21635478-nearly-half-newfederal-employees-are-military-veterans-what-next, dostęp 12.03.2015.

${ }^{44}$ Executive Order 13518 - Veterans Employment Initiative. Zarządzenie regulujące zwiększenie szans weteranów na zatrudnienie w sektorze administracji publicznej. Obejmuje trzy główne cele: wypełnienie zobowiązań wobec weteranów, wykorzystanie umiejętności i talentu weteranów w związku z wyzwaniami, jakie czekają administrację publiczną, stworzenie programu, który będzie wzorcem i wyznacznikiem dla sektora prywatnego. Zgodnie z zarządzeniem weterani mogą podejmować pracę w 24 wymienionych $\mathrm{w}$ akcie normatywnym departamentach i instytucjach publicznych, https://www.whitehouse.gov/the-press-office/executive-order-veterans-employment-initiative, dostęp 9.09.2015.

${ }^{45} \mathrm{~L}$. Rein, Record numbers of veterans are getting jobs in the government - but a lot of them quit, http:// www.washingtonpost.com/blogs/federal-eye/wp/2015/08/28/record-numbers-of-veterans-are-gettingjobs-in-the-government-but-a-lot-of-them-arent-staying/, dostęp 12.09.2015.

46 Troops to Truckers to inicjatywa niosąca pomoc weteranom szukającym zatrudnienia w sektorze transportu. Program traktuje każdego weterana jednakowo i bez ograniczeń, pomoc oferowana jest bez względu na rodzaj niepełnosprawności, czas służby, pochodzenie, rasę, narodowość, płeć, orientację seksualną czy sytuację finansową. Ponadto program pomaga w znalezieniu zatrudnienia najbliższym członkom rodziny weterana, http://troopstotruckers.com/, dostęp 12.09.2015. 
Helmets to Hardhats, ${ }^{47}$ Troops to Trades ${ }^{48}$ Warriors4Wireless, ${ }^{49}$ Boots to Business ${ }^{50}$ czy Solar Ready Vets ${ }^{51}$ to przykłady takich inicjatyw. Często organizacje wspierające weteranów działają tylko na terenie danego stanu, kojarząc lokalnych przedsiębiorców z weteranami. Przykładem takiej akcji jest zapoczątkowany w 2010r. przez gubernatora Missouri J. Nixona projekt Show-Me Heroes ${ }^{52}$, dzięki któremu Gwardia Narodowa Stanu Missouri może przygotowywać żołnierzy do wejścia na cywilny rynek pracy. Na podobnej zasadzie działa w Kalifornii program Work for Warriors $^{53}$ oraz w Nowym Jorku American Corporate Partners ${ }^{54}$. Największą platformą wspomagającą zatrudnienie weteranów w sektorze rządowym jest FedsHireVets ${ }^{55}$ prowadzone przez Biuro Zarząadzania Personelem ${ }^{56}$ (U.S. Office of Personnel Management). Aktualnie weterani reprezentują 30,8\% wszystkich pracowników sektora federalnego ${ }^{57}$. Warto zwrócić uwagę, że wśród zatrudnionych weteranów większość

${ }^{47}$ Helmets to Hardhats to inicjatywa mająca na celu pomoc weteranom w znalezieniu zatrudnienia w budownictwie, https://www.helmetstohardhats.org/, dostęp 12.09.2015.

${ }^{48}$ Troops to Trades to program pomocy weteranom w znalezieniu zatrudnienia w obszarze usług, takich jak hydraulika, elektryka, montaż klimatyzacji, http://www.troopstotrades.org/, dostęp 12.09.2015.

${ }^{49}$ Warriors4Wireless jest organizacją non-profit utworzoną w celu wypełnienia zapotrzebowania na wykwalifikowanych techników systemów bezprzewodowych, gotowych do wykorzystania umiejętności zdobytych w wojsku. Organizacja oferuje weteranom szkolenia, certyfikację i pomaga w rozwoju kariery w branży telekomunikacyjnej. Z organizacją współpracują m.in. American Tower, Crown Castle, MasTec Network Solutions, Shenandoah Tower Services, Site Link, http://warriors4wireless.org/, dostęp 12.09.2015.

${ }^{50}$ Boots to Business jest rządowym programem edukacyjnym oferowanym przez federalną agencję ds. małych i średnich przedsiębiorstw (U.S. Small Business Administration) oraz Departament Obrony (Transition Assistance Program) na rzecz innowacji. Program oferuje żołnierzom planującym zakończyć służbę oraz weteranom szkolenia z zakresu prowadzenia własnej działalności gospodarczej i wprowadzania na rynek innowacyjnych rozwiązań biznesowych. Program jest obecny w 165 amerykańskich bazach wojskowych na całym świecie. Dotychczas przeszkolono ponad 25 tys. żołnierzy i weteranów, http://boots2business.org/, dostęp 12.09.2015.

${ }^{51}$ Solar Ready Vets to jeden z najnowszych programów rządowych, wprowadzony we wrześniu $2014 \mathrm{r}$. przez Departament Energii Stanów Zjednoczonych (U.S. Department of Energy). Dzięki tej inicjatywie żołnierze i weterani przygotowywani są do pracy w sektorze energii odnawialnej, zwłaszcza w obszarze wykorzystywania energii słonecznej, jako menedżerowie, technicy, sprzedawcy oraz właściciele firm o takim właśnie profilu. Większość weteranów (39\%) pracuje przy montażu urządzeń, natomiast $27 \%$ przy produkcji. Na uwagę zasługują dość wysokie zarobki weteranów, średnia płaca za godzinę wynosi 19 USD (montaż), 15 USD (produkcja), http://blogs.marketwatch.com/energy-ticker/2014/02/26/solaremploys-higher-rate-of-veterans-than-other-industries/, dostęp 15.08.2015. W ciągu ostatnich czterech lat zatrudnienie w przemyśle solarnym wzrosło w Stanach Zjednoczonych o 86\%. W 2014 r. na każde 78 nowych miejsc pracy, jedno powstawało w sektorze energii solarnej, http://energy.gov/eere/sunshot/solar-ready-vets, dostęp 15.08.2015.

52 Show-Me Heroes, http://showmeheroes.mo.gov/, dostęp 15.08.2015.

${ }_{53}$ Work for Warriors, http://www.workforwarriors.org/, dostęp 15.08.2015.

54 American Corporate Partners, http://acp-usa.org/, dostęp 17.08.2015.

${ }^{55}$ Feds Hire Vets, http://www.fedshirevets.gov/, dostęp 17.08.2015.

56 U.S. Office of Personnel Management, https://www.opm.gov/, dostęp 17.08.2015.

57 Employment of Veterans in the Federal Executive Branch Fiscal Year 2014, U.S. Office of Personnel Management, July 2015, http://www.fedshirevets.gov/hire/hrp/reports/EmploymentOfVets-FY14.pdf, dostęp 9.09.2015. 
stanowią weterani uprzywilejowani ${ }^{58}$, natomiast $11,4 \%$ wszystkich zatrudnionych w 2014 r. w administracji publicznej to inwalidzi wojenni. Szczegółowe dane zostały przedstawione w tabelach 6 i 7.

Tabela 6. Poziom zatrudnienia amerykańskich weteranów $\mathrm{w}$ administracji publicznej w latach 2010-2014

\begin{tabular}{|l|r|r|r|r|r|}
\hline \multicolumn{1}{|c|}{ Kategoria } & 2010 & 2011 & 2012 & 2013 & 2014 \\
\hline $\begin{array}{l}\text { Osoby zatrudnione w administracji } \\
\text { publicznej }\end{array}$ & 2061435 & 2079258 & 2058670 & 2015225 & 1990033 \\
\hline $\begin{array}{l}\text { Weterani zatrudnieni w administracji } \\
\text { publicznej }\end{array}$ & 542641 & 567314 & 611784 & 607145 & 612661 \\
\hline \% wszystkich pracowników & 26,3 & 27,3 & 29,7 & 30,1 & 30,8 \\
\hline Weterani uprzywilejowani & 484806 & 502887 & 511749 & 510991 & 516075 \\
\hline \% wszystkich pracowników & 23,5 & 24,2 & 24,9 & 25,4 & 25,9 \\
\hline \% wszystkich weteranów & 89,3 & 88,6 & 83,6 & 84,2 & 84,2 \\
\hline Weterani niepełnosprawni & 145062 & 159082 & 200938 & 213265 & 226013 \\
\hline \% wszystkich pracowników & 7,0 & 7,7 & 9,8 & 10,6 & 11,4 \\
\hline \% wszystkich weteranów & 26,7 & 28,0 & 32,8 & 35,1 & 36,9 \\
\hline Weterani z min. 30\% niepełnosprawnością & 88778 & 100386 & 111303 & 121200 & 132434 \\
\hline \% wszystkich pracowników & 4,3 & 4,8 & 5,4 & 6,0 & 6,7 \\
\hline \% wszystkich weteranów & 16,4 & 17,7 & 18,2 & 20,0 & 21,6 \\
\hline
\end{tabular}

Źródło: Employment of Veterans in the Federal Executive Branch Fiscal Year 2014, U.S. Office of Personnel Management, July 2015, http://www.fedshirevets.gov/hire/hrp/reports/EmploymentOfVets-FY14.pdf

Tabela 7. Liczba nowo zatrudnionych weteranów $\mathrm{w}$ administracji publicznej w latach 2010-2014

\begin{tabular}{|l|r|r|r|r|r|}
\hline \multicolumn{1}{|c|}{ Kategoria } & 2010 & 2011 & 2012 & 2013 & 2014 \\
\hline $\begin{array}{l}\text { Osoby nowo zatrudnione w administracji } \\
\text { publicznej }\end{array}$ & 281651 & 229853 & 195139 & 162839 & 180562 \\
\hline $\begin{array}{l}\text { Weterani nowo zatrudnieni w administracji } \\
\text { publicznej }\end{array}$ & 72133 & 65030 & 56422 & 50502 & 59992 \\
\hline \% wszystkich pracowników & 25,6 & 28,3 & 28,9 & 31,0 & 33,2 \\
\hline Weterani uprzywilejowani & 64747 & 58550 & 50165 & 45569 & 53608 \\
\hline
\end{tabular}

${ }^{58}$ Rozdział 5, sekcja 2108 Kodeksu Stanów Zjednoczonych reguluje stanowisko weterana uprzywilejowanego, który ma pierwszeństwo przy zatrudnieniu w administracji państwowej. Przebieg służby weterana i poszczególne dokonania podlegają systemowi rankingowemu i punktowane są w skali od 0 do 10. Uprzywilejowani są weterani, którzy bezpośrednio uczestniczyli w działaniach wojennych (5 pkt), mają stopień niepełnosprawności w związku z pełnieniem służby wojskowej (10 pkt) lub posiadają odznaczenie Purple Heart (10 pkt), http://www.fedshirevets.gov/job/vetpref/, dostęp 10.09.2015. 


\begin{tabular}{|l|r|r|r|r|r|}
\hline \multicolumn{1}{|c|}{ Kategoria } & \multicolumn{1}{c|}{2010} & \multicolumn{1}{c|}{2011} & \multicolumn{1}{c|}{2012} & \multicolumn{1}{c|}{2013} & \multicolumn{1}{c|}{2014} \\
\hline \% wszystkich pracowników & 23,0 & 25,5 & 25,7 & 28,0 & 29,7 \\
\hline \% wszystkich weteranów & 89,8 & 90,0 & 88,9 & 90,2 & 89,4 \\
\hline Weterani niepełnosprawni & 23140 & 20613 & 21589 & 20838 & 25690 \\
\hline \% wszystkich pracowników & 8,2 & 9,0 & 11,1 & 12,8 & 14,2 \\
\hline \% wszystkich weteranów & 32,1 & 31,7 & 38,3 & 41,3 & 42,8 \\
\hline Weterani z min. 30\% niepełnosprawnością & 15435 & 13969 & 12926 & 12427 & 16301 \\
\hline \% wszystkich pracowników & 5,5 & 6,1 & 6,6 & 7,6 & 9,0 \\
\hline \% wszystkich weteranów & 21,4 & 21,5 & 22,9 & 24,6 & 27,2 \\
\hline
\end{tabular}

Źródło: Employment of Veterans in the Federal Executive Branch Fiscal Year 2014, U.S. Office of Personnel Management, July 2015, http://www.fedshirevets.gov/hire/hrp/reports/EmploymentOfVets-FY14.pdf

W Stanach Zjednoczonych nikt nie będzie zaskoczony słysząc, że 46,9\% pracowników cywilnych Departamentu Obrony stanowią weterani. Pozostałe departamenty i agencje rządowe nie pozostają w tyle, weterani stanowią $36,4 \%$ kadry w Departamencie Transportu, 28,2\% w Departamencie Sprawiedliwości i 22,9\% w Departamencie Energii. Niepełnosprawność weterana lub posiadanie przez niego odznaczenia wojskowego Purple Heart ${ }^{59}$ nadawanego w imieniu prezydenta Stanów Zjednoczonych niejednokrotnie otwierają drogę do zatrudnienia $\mathrm{w}$ administracji publicznej. W niektórych instytucjach urzędnicy są zobligowani do zatrudnienia weteranów, jeżeli spełniają oni formalne wymogi. Współmałżonek poległego lub ciężko rannego żołnierza może być wyznaczony na stanowisko w administracji publicznej poza konkurencją ${ }^{60}$. Szczegółowy poziom zatrudnienia weteranów w $2014 \mathrm{r}$. w administracji publicznej przedstawia tabela 8. Rząd federalny tworzy łącznie 15\% miejsc pracy dla wszystkich weteranów, $85 \%$ sektor prywatny ${ }^{61}$.

${ }^{59}$ Purple Heart to ustanowione 3 lutego 1932 r. jedno z najważniejszych odznaczeń wojskowych nadawanych przez prezydenta Stanów Zjednoczonych tym, którzy zostali ranni lub zginęli podczas wykonywania obowiązków służbowych.

${ }^{60}$ Veterans: What next?, http://www.economist.com/news/united-states/21635478-nearly-half-newfederal-employees-are-military-veterans-what-next, dostęp 12.03.2015.

${ }^{61}$ F. Lucas, Why Is the Jobless Rate for Iraq and Afghanistan Veterans so High?, http://www.theblaze. com/stories/2013/10/25/why-is-the-jobless-rate-for-iraq-and-afghanistan-veterans-so-high/, dostęp 20.12.2014. 
Tabela 8. Poziom zatrudnienia amerykańskich weteranów w poszczególnych instytucjach administracji publicznej w 2014 r.

\begin{tabular}{|c|c|c|c|}
\hline Instytucja & Pracownicy & Weterani & $\%$ \\
\hline Wszyscy zatrudnieni & 1990033 & 612,661 & 30,8 \\
\hline Departament Rolnictwa & 95917 & 11450 & 11,9 \\
\hline Departament Handlu & 45380 & 5384 & 11,9 \\
\hline Departament Obrony & 668964 & 313881 & 46,9 \\
\hline Departament Edukacji & 4195 & 444 & 10,6 \\
\hline Departament Energii & 14992 & 3426 & 22,9 \\
\hline Departament Zdrowia i Opieki Społecznej & 84588 & 6054 & 7,2 \\
\hline Departament Bezpieczeństwa Krajowego & 189341 & 52732 & 27,9 \\
\hline Departament Urbanizacji & 8444 & 1239 & 14,7 \\
\hline Departament Zasobów Wewnętrznych & 69955 & 11572 & 16,5 \\
\hline Departament Sprawiedliwości & 113240 & 31892 & 28,2 \\
\hline Departament Pracy & 15940 & 3316 & 20,8 \\
\hline Departament Stanu & 12694 & 2516 & 19,8 \\
\hline Departament Transportu & 54776 & 19914 & 36,4 \\
\hline Departament Skarbu & 92619 & 10523 & 11,4 \\
\hline Departament Spraw Weteranów & 348724 & 114740 & 32,9 \\
\hline Agencja Rozwoju Międzynarodowego & 1698 & 248 & 14,6 \\
\hline Agencja Ochrony Środowiska & 15852 & 1267 & 8,0 \\
\hline Generalny Urząd ds. Usług & 11501 & 2492 & 21,7 \\
\hline NASA & 17691 & 2091 & 11,8 \\
\hline Narodowa Fundacja Nauki & 1425 & 123 & 8,6 \\
\hline Biuro Zarządzania Personelem & 4977 & 1173 & 23,6 \\
\hline Nuklearna Komisja Regulacyjna & 3871 & 825 & 21,3 \\
\hline Urząd ds. Ubezpieczeń Społecznych & 64684 & 9127 & 14,1 \\
\hline Urząd ds. Małych Przedsiębiorstw & 4549 & 756 & 16,6 \\
\hline
\end{tabular}

Źródło: Employment of Veterans in the Federal Executive Branch Fiscal Year 2014, U.S. Office of Personnel Management, July 2015, http://www.fedshirevets.gov/hire/hrp/reports/EmploymentOfVets-FY14.pdf

Taki napływ weteranów do administracji publicznej może być bardzo korzystny. Cenione są ich doświadczenia służby wojskowej, gdzie wykonanie zadania nakazanego przez przełożonego wynikało wręcz z regulaminu. Ogólna sytuacja weteranów na rynku pracy nie była zła od zawsze. Artykuł C. Coile, M. Duggana i A. Guo wskazuje, że w latach 1980-2000 weterani poszukiwali pracy znacznie częściej i efektywniej niż inni obywatele. Zmieniło się to od momentu zaangażowania Stanów Zjednoczonych w Iraku i Afganistanie. Od tego czasu zwiększyła się liczba weteranów otrzymujących wypłaty rent. Po II wojnie światowej około $15 \%$ weteranów wystąpiło o przyznanie rent, po wojnie w Wietnamie wskaźnik ten wzrósł do $25 \%$, obecnie sięga prawie $50 \%$. Jednym z głównych powodów takiego stanu rzeczy są udoskonalenia medycyny pola 
walki oraz indywidualnego wyposażenia każdego żołnierza. Ochrona, jaką zapewniają obecne hełmy i kamizelki kuloodporne, pozwala na przeżycie wybuchu, który jeszcze dwie dekady temu okazywał się dla żołnierza śmiertelny ${ }^{62}$. Żołnierze przeżywają, ale niejednokrotnie wracają do domu z traumatycznym urazem mózgu (Traumatic Brain Injury) lub objawami PTSD, które w sposób szczególny mają wpływ na dalsze losy weterana na rynku pracy.

\section{Perspektywy i możliwości}

Służba wojskowa wyposaża żołnierzy w pożądaną na cywilnym rynku pracy wiedzę, nie tylko techniczną - daje umiejętności interpersonalne, uczy przywództwa i pracy zespołowej. Wiedza, w którą wyposażani są żołnierze podczas rygorystycznych szkoleń, z powodzeniem może być wykorzystana w środowisku cywilnym ${ }^{63}$. Aktualnie uwaga amerykańskiej opinii publicznej koncentruje się przede wszystkim na weteranach pokolenia 9/11. Stopa bezrobocia wśród amerykańskich weteranów wynosiła w $2014 \mathrm{r}$. $5,3 \%$ (6,6\% w 2013 r.) i była mniejsza niż dla całej populacji (6,0\% w 2014 r., 7,2\% w 2013 r.). Jednak najbardziej niepokojące jest bezrobocie w grupie najmłodszych weteranów (18-24 lata) opuszczających siły zbrojne (16,2\%). To uczestnicy wojen w Iraku i Afganistanie. Sytuację pogarsza fakt, że wśród przedsiębiorców panuje mylne przekonanie o najmłodszych weteranach, którzy cierpią na syndrom stresu pourazowego i mogą stwarzać niepotrzebne problemy w miejscu pracy ${ }^{64}$. W tej samej grupie wiekowej bezrobocie wśród osób, które nie służyły w wojsku wynosiło w 2014r. 12,5\%. Wygaszanie obecności Amerykanów w Afganistanie, połączone z cięciami na obronę, spowoduje, że z sił zbrojnych będzie musiało odejść w ciągu najbliższych pięciu lat około miliona żołnierzy ${ }^{65}$. Większość z nich zasili rynek pracy. Problemy z weteranami będą więc narastać, stając się wyrzutem sumienia kolejnych administracji ${ }^{66}$. Amerykańska gospodarka potrzebuje weteranów. Przejście żołnierza

62 C. Coile, M. Duggan, A. Guo, Veterans'Labor Force Participation: What Role Does the VA's Disability Compensation Program Play?, "American Economic Review" 2015, Vol. 115, No. 5, American Economic Association, s. 134.

${ }^{63}$ America's Heroes at Work - Veterans Hiring Toolkit, Top Ten Reasons to Hire Veterans and Wounded Warriors, U.S. Department of Labor, http://www.dol.gov/vets/ahaw/topten.htm, dostęp 1.09.2015.

64 A. Schneider, Iraq and Afghanistan War Veterans Still Battling Unemployment, http://www.houstonpublicmedia.org/news/iraq-and-afghanistan-war-veterans-still-battling-higherthanaverage-unemployment/, dostęp 16.02.2015.

65 T. Deptuła, USA: niełatwe powroty weteranów, http://www.ekonomia.rp.pl/artykul/1063797.html, dostęp 16.06.2015.

66 Trudny problem: weterani, http://www.dziennik.com/publicystyka/artykul/trudny-problem-weterani, dostęp 20.04.2015. 
do cywila jest swego rodzaju stratą dla armii, ale zyskiem dla społeczeństwa. Mimo silnego wsparcia ze strony administracji publicznej oraz organizacji zajmujących się weteranami, system pomocy nadal nie jest doskonały. Powodem trudności weteranów na rynku pracy jest wiele czynników, zaczynając od wykształcenia, kończąc na zaangażowaniu i determinacji w poszukiwaniu pracy. W kwietniu 2015 r. Sekretarz Obrony Stanów Zjednoczonych Ash Carter przyznał w jednym z wywiadów, że proces rekonwersji, przygotowywania weterana do wejścia na cywilny rynek pracy, powinien być podejmowany zdecydowanie wcześniej, tak aby każdy żołnierz opuszczający armię wiedział, czego może się spodziewać w nowej cywilnej rzeczywistości ${ }^{67}$.

Tabela 9. Wskaźnik zatrudnienia i bezrobocia wśród amerykańskich weteranów pokolenia 9/11 (kobiet i mężczyzn) w 2014r. a miejsce pełnienia służby (w tys.)

\begin{tabular}{|c|c|c|c|c|c|}
\hline $\begin{array}{l}\text { Miejsce pełnienia } \\
\text { służby }\end{array}$ & Populacja & $\begin{array}{l}\text { Siła robocza } \\
\text { (\% populacji) }\end{array}$ & $\begin{array}{l}\text { Zatrudnieni } \\
\text { (\% populacji) }\end{array}$ & $\begin{array}{c}\text { Bezrobotni } \\
\text { (\% sity roboczej) }\end{array}$ & Poza siłą roboczą \\
\hline $\begin{array}{l}\text { Wszyscy weterani } \\
\text { pokolenia } 9 / 11\end{array}$ & 3154 & $\begin{array}{l}2,484 \\
(78,8)\end{array}$ & $\begin{array}{l}2,282 \\
(72,4)\end{array}$ & $\begin{array}{l}201 \\
(8,1)\end{array}$ & 670 \\
\hline Irak & 955 & $\begin{array}{c}759 \\
(79,5)\end{array}$ & $\begin{array}{c}706 \\
(73,9)\end{array}$ & $\begin{array}{c}54 \\
(7,1)\end{array}$ & 195 \\
\hline Afganistan & 444 & $\begin{array}{c}338 \\
(76,3)\end{array}$ & $\begin{array}{c}303 \\
(68,2)\end{array}$ & $\begin{array}{c}36 \\
(10,5)\end{array}$ & 105 \\
\hline Irak i Afganistan & 260 & $\begin{array}{c}208 \\
(79,8)\end{array}$ & $\begin{array}{c}193 \\
(74,2)\end{array}$ & $\begin{array}{c}14 \\
(6,9)\end{array}$ & 53 \\
\hline Inna Iokalizacja & 1403 & $\begin{array}{l}1,166 \\
(83,1)\end{array}$ & $\begin{array}{l}1,075 \\
(76,6)\end{array}$ & $\begin{array}{c}91 \\
(7,8)\end{array}$ & 238 \\
\hline
\end{tabular}

Źródło: opracowanie własne na podstawie Employment Situation of Veterans 2014, USDL-15-0426, Bureau of Labor Statistics, U.S. Department of Labor, http://www.bls.gov/news.release/vet.t10.htm

Żołnierze rozpoczynający służbę uczeni są podstawowych wartości obowiązujących nie tylko w służbie. Zawarte są one w akronimie LDRSHIP (Loyalty, Duty, Respect, Selfless service, Honor, Integrity, Personal courage), czyli lojalność, obowiązek, szacunek, bezinteresowna służba, uczciwość, odwaga. Ponadto wojsko rozwija u żołnierzy takie cechy jak dyscyplina, punktualność, poczucie karności; inicjatywę i determinację, które wśród cywilnych osób zatrudniających powinny być pożąane ${ }^{68}$. Celem jest pozbycie się złych nawyków wśród młodych żołnierzy, a następnie zbudowanie odpowiednich wartości. Wielokrotnie młodzi żołnierze otrzymują do obsługi

67 J. Harper, Carter: Time to think about post-military career is while still serving, http://www.stripes. com/news/carter-time-to-think-about-post-military-career-is-while-still-serving-1.337836, dostęp 9.08.2015.

68 D.S. Loughran, Why Is Veteran Unemployment So High?, RAND Corporation, 2014, s. 21, http:// www.rand.org/content/dam/rand/pubs/research_reports/RR200/RR284/RAND_RR284.pdf, dostęp 9.09.2015. 
sprzęt wojskowy wart kilkaset tysięcy USD, powierzane są im informacje niejawne, stają na czele kilkunastoosobowego zespołu, którym muszą dowodzić. To procentuje później na cywilnym rynku pracy. Odpowiednia polityka uświadamiająca istotę samodyscypliny, rozwoju zawodowego, inwestycji w wykształcenie, rzetelnej selekcji i doboru kadr do wojska wydają się być konieczne już na początku drogi każdego kandydata na żołnierza. Potrzebni są przedsiębiorcy, którzy odłożą na bok błędne wyobrażenia o weteranach i zastanowią się nad umiejętnościami i poszczególnymi zaletami, jakie byli żołnierze mogą wnieść do danej instytucji. W interesie Ameryki jest zatrudnianie weteranów. Takie działania spowodują zacieśnienie więzi weteranów ze społeczeństwem, natomiast ekonomia państwa będzie bardziej konkurencyjna. Poza tym wskaże osobom rozważającym włożenie munduru, że służba wojskowa może być dobrym krokiem w kierunku przyszłej kariery ${ }^{69}$.

Dlaczego więc bezrobocie wśród weteranów wojny w Afganistanie jest tak wysokie? RAND Corporation przedstawił w 2014 r. pięć najbardziej powszechnych w społeczeństwie amerykańskim przyczyn wysokiego wskaźnika bezrobocia wśród weteranów pokolenia 9/11. Obejmują one: zły stan zdrowia weteranów (w opinii wielu służba wojskowa powoduje choroby fizyczne i psychiczne, schorzenia natomiast powodują problemy ze znalezieniem pracy), dyskryminację ze strony zatrudniającego (przedsiębiorcy są uprzedzeni do weteranów), wybór drogi zawodowej (osoby, które zdecydowały się na służbę wojskową mają cechy, które w przyszłości zmniejszą ich szanse na zatrudnienie w środowisku cywilnym), niedopasowanie posiadanych kwalifikacji do wymagań (armia szkoli żołnierzy w dziedzinach, których nie można przełożyć na rynek cywilny) oraz brak umiejętności skutecznego poszukiwania pracy ${ }^{70}$. Większość tych hipotez ma jednak niewielkie oparcie w danych ogólnodostępnych. Istnieją natomiast dowody popierające hipotezę, że wyższy wskaźnik bezrobocia wśród młodych weteranów jest wynikiem procesu odchodzenia do cywila, przekwalifikowywania się i poszukiwania pracy. Proces ten, co wydaje się naturalne, wymaga czasu. Ponadto znalezienie pracy było utrudnione zwłaszcza w okresach spowolnionego rozwoju gospodarczego. W tym sensie weterani są w gorszej sytuacji na rynku pracy. Nie można jednak twierdzić, że wybór zawodu żołnierza jest wyborem złym. Weterani są jednostką już wyselekcjonowaną, każdego roku ponad 150 tys. mężczyzn i kobiet wstępuje do armii Stanów Zjednoczonych ${ }^{71}$. Kandydaci zgłaszają się dobrowolnie,

${ }^{69}$ J. Jones, D. Goldberg, Put veterans to work, http://www.latimes.com/opinion/op-ed/la-oe-jonesemploy-veterans-20131111-story.html\#axzz²kROfV4nY, dostęp 14.01.2015.

70 D.S. Loughran, op.cit., s. 17.

${ }^{71}$ D.S. Loughran, P. Martorell, T. Miller, J.A. Klerman, The Effect of Military Enlistment on Earnings and Education, RAND Corporation, Santa Monica, 2011, s. III. http://www.rand.org/content/ dam/rand/pubs/technical_reports/2011/RAND_TR995.pdf, dostęp 9.09.2015. 
by służyć w wojsku, natomiast komisje kwalifikacyjne wybierają najlepszych, biorąc pod uwagę takie czynniki jak zdolności, talent, osiągnięcia edukacyjne, stan zdrowia, obywatelstwo czy karalność ${ }^{72}$. Amerykańska gospodarka nie jest w stanie zapewnić pracy wszystkim weteranom odchodzącym ze służby, zwłaszcza tym, którzy nie posiadają minimalnych kwalifikacji. Mimo że osoby zatrudniające nie do końca znają specyfikę takich specjalności wojskowych jak snajper, strzelec karabinu maszynowego, kierowca czołgu czy dowódca załogi śmigłowca, to problem z wykorzystaniem umiejętności nabytych podczas służby również nie do końca wydaje się być racjonalny. Weterani, których specjalizacja wojskowa nie ma odpowiednika na cywilnym rynku pracy mają ograniczone możliwości zdobycia nowej pracy bez przekwalifikowania lub zdobycia wykształcenia, jednakże $81 \%$ specjalności wojskowych ma swój bezpośredni lub bardzo zbliżony cywilny odpowiednik. Wojsko posiada w swoich kadrach inżynierów, pielęgniarki, prawników, księgowych, kierowców, informatyków, specjalistów do spraw telekomunikacji, logistyki itd. ${ }^{73}$. Zatem pewne umiejętności zawodowe, które młodzi weterani nabywają w wojsku, z powodzeniem wykorzystują później na cywilnym rynku pracy. Co więcej, na potrzeby weteranów i osób zatrudniających zostały opracowane specjalne systemy, które „tłumaczą” specjalności wojskowe (Military Occupation Specialties) na cywilne, wskazując jednocześnie oferty pracy ${ }^{74}$. Od 2010 r. wszystkie 50 stanów oraz Puerto Rico uchwaliły ustawy ułatwiające szybsze podjęcie pracy przez weteranów w powyższych specjalnościach. Dzięki zapisom legislacyjnym honorowane są niektóre licencje, nie ma konieczności ponownego szkolenia i certyfikowania ${ }^{75}$. Efektem zatrudnienia weteranów jest nie tylko dochód, ale także sens przynależności, bycie częścią społeczeństwa. W dalszym ciągu niezbędne jest prowadzenie polityki informacyjnej dla menedżerów o wartościach, jakie mogą wnieść do firmy weterani, prowadzenie rekrutacji w sposób bardziej strategiczny, docierając do weteranów lub uczestnicząc w targach pracy. Racjonalnym kierunkiem jest działanie Departamentu Obrony, który zamierza kontynuować rozwijanie na terenie baz wojskowych programów rekonwersyjnych, umożliwiających przekwalifikowanie żołnierzy planujących odejść do cywila ${ }^{76}$. Głos w sprawie zatrudniania najmłodszych weteranów wojen w Iraku i Afganistanie zabrał

72 Ibidem, s. 5.

73 T.L. Daywalt, Testimony given at House Committee on Veteran Affairs, Veterans Employment Summit, Washington, DC, September 13, 2011, s. 24, https://veterans.house.gov/sites/republicans.veterans. house.gov/files/documents/VetJobs.pdf, dostęp 1.09.2015.

${ }_{74}$ Skills Translator, http://www.military.com/veteran-jobs/skills-translator/, dostęp 15.07.2015.

75 J. Schultz, State help for returning veterans, National Conference of State Legislatures, http://www. ncsl.org/research/military-and-veterans-affairs/state-help-for-returning-veterans.aspx, dostęp 12.09.2015.

76 K.C. Hall, M.C. Harrell, B. Bicksler, R. Stewart, M.P. Fisher, Veteran Employment. Lessons from the 100,000 Jobs Mission, RAND Corporation, 2014, s. 29-30, http://www.rand.org/content/dam/rand/pubs/research_reports/RR800/RR836/RAND_RR836.pdf, dostęp 12.09.2015. 
także gen. D. Petraeus, aktualnie przewodniczący Global Institute w Kohlberg Kravis Roberts \& Co. ${ }^{77}$, dyrektor CIA w latach 2011-2012 oraz m.in. były dowódca wojsk amerykańskich w Afganistanie. Zdaniem gen. Petraeusa przedsiębiorstwa powinny zachęcać do pracy we własnych szeregach, oferować szkolenia, umożliwiać kontynuowanie edukacji oraz rozwój zawodowy ${ }^{78}$. Pojawiają się także głosy, by młodzi weterani szli śladem swoich cywilnych rówieśników ${ }^{79}$ i rozwijali wiedzę na kursach i studiach w obszarze dyscyplin naukowych STEM ${ }^{80}$. Może to w sposób znaczący zwiększyć szansę weteranów na zatrudnienie na cywilnym rynku pracy w związku $\mathrm{z}$ gwałtownym rozwojem inżynierii oraz nowych technologii ${ }^{81}$.

Każdego dnia ok. 550 żołnierzy rozstaje się z mundurem i zaczyna nowe życie w cywilnej rzeczywistości ${ }^{82}$. Przewiduje się, że w ciągu najbliższych pięciu lat siły zbrojne Stanów Zjednoczonych opuści każdego roku prawie 250 tys. żołnierzy ${ }^{83}$. Niektórzy wrócą na cywilny rynek pracy niepełnosprawni, wskutek ran fizycznych i psychicznych. Większość stawi czoło nowemu wyzwaniu, jakim będzie znalezienie nowej pracy i nauka nowych umiejętności. Rząd stara się im w tym pomagać. W procedury zaangażowały się Departamenty: Obrony, Pracy oraz Spraw Weteranów. Ten ostatni, z myślą o weteranach niepełnosprawnych oraz żołnierzach Gwardii Narodowej i Rezerwy, opracował program VR\&E (Vocational Rehabilitation and Employment) ${ }^{84}$, znany również jako „Uchwała 31”, dzięki któremu weterani przez 48 miesięcy mogą otrzymywać pomoc rehabilitacyjną, uczyć się samodzielności pod okiem opiekuna oraz uzyskać doradztwo w zakresie zatrudnienia weterana niepełnosprawnego na rynku pracy ${ }^{85}$. Stale starają się ulepszać programy rządowe, które przygotują żołnierzy do życia poza wojskiem. Obecnie od wszystkich planujących odejście z wojska wymaga

77 Kohlberg Kravis Roberts \& Co. to spółka zajmująca się prywatnymi inwestycjami kapitałowymi (private equity) oraz zakupami lewarowanymi (leveraged buyout), http://www.kkr.com/, dostęp 20.09.2015.

${ }^{78}$ E. Jager, Petraeus: Returning Veterans Deserve More than 'Dead-End Jobs', http://www.newsmax. com/US/veterans-petraeus-goodfriend-jobs/2014/01/22/id/548294/, dostęp 15.07.2015.

${ }_{79}$ R. Litan, Why Do Young Veterans Have So Much Trouble Finding Jobs?, http://blogs.wsj.com/washwire/2014/10/01/why-do-young-veterans-have-so-much-trouble-finding-jobs/, dostęp: 19.01.2015.

${ }^{80}$ STEM (Science, Technology, Engineering, Mathematics), akronim oznaczający przedmioty ścisłe, takie jak technologia, inżynieria, matematyka.

${ }_{81}$ D. Smith-Barrow, For Veterans to Prosper in STEM Workforce, Employers Need to Help With PostMilitary Transition, http://www.usnews.com/news/stem-solutions/articles/2015/06/30/for-veterans-toprosper-in-stem-workforce-employers-need-to-help-with-post-military-transition, dostęp 15.08.2015.

${ }_{82}$ Difficult transitions, http://www.economist.com/blogs/democracyinamerica/2014/11/veterans-day, dostęp 5.09.2015.

${ }^{83}$ Office of the Chairman of the Joint Chiefs of Staff (White paper), Enabling Collaborative Support to Reintegrate the Military Family, 2014, s. 4, http://www.jcs.mil/Portals/36/Documents/CORe/141103_Enabling_Collaborative_Support.pdf, dostęp 5.09.2015.

${ }^{84}$ VR\&E Program: The Basics, https://www.vets101.org/a/38/, dostęp 7.09.2015.

85 Weterani uprawnieni do korzystania z programu VR\&E muszą spełniać określone wymogi: nie mogą być zwolnieni z wojska dyscyplinarnie, niepełnosprawność związana ze służbą wojskową musi sięgać co najmniej 10\% uszczerbku na zdrowiu oraz znacznie utrudniać pracę (lub 20\% i ograniczać 
się ukończenia kursu Transition GPS ${ }^{86}$ (Goals, Plans, Success) - specjalnego programu rządowego, który uczy przyszłych weteranów, jak przygotować życiorys i aplikować o pracę. Głównym zamierzeniem kursu jest pomoc żołnierzom w przeniesieniu ich umiejętności nabytych w wojsku na cywilny rynek pracy.

Zdarza się, że pomoc finansowa ze strony państwa staje się czynnikiem zniechęcającym weteranów do aktywnego poszukiwania pracy. Dla przykładu weźmy wysokość renty, która uzależniona jest od procenta uszczerbku na zdrowiu. W wypadku stwierdzenia u weterana PTSD wskaźnik niepełnosprawności wynosi 60-70\%, utraty nogi - 100\%. Najszybciej rosnąca grupa weteranów to ta, która zrezygnowała $\mathrm{z}$ podjęcia pracy $\mathrm{w}$ imię otrzymywania renty z tytułu niepełnosprawności. Zgodnie z przepisami Departamentu Spraw Weteranów niepełnosprawność sięgająca min. 60\% kwalifikowana jest jako ograniczona zdolność do podjęcia pracy i z tego tytułu weteranowi posiadającemu małżonka i dziecko rząd wypłaca kwotę 3100 USD miesięcznie ${ }^{87}$. Otrzymywana comiesięczna renta dla części weteranów przestaje być bodźcem do poszukiwania pracy. Weterani, których niepełnosprawność sięga 30\%, mogą być uprawnieni do otrzymywania dodatkowych świadczeń od państwa, takich jak rehabilitacja, odnawianie domów, przydzielanie osoby do pomocy lub zapewnienie usług protetycznych ${ }^{88}$. Innym przykładem jest permanentne korzystanie z programów rządowych, takich jak UCX (Unemployment Compensation Ex-Servicemembers), przeznaczonych dla byłych żołnierzy służby czynnej, którzy przesłużyli co najmniej jeden kontrakt oraz nie zostali zwolnieni ze służby dyscyplinarnie. Żołnierze Gwardii Narodowej oraz Rezerwy muszą przesłużyć nieprzerwanie co najmniej 90 dni, by uzyskać to świadczenie ${ }^{89}$. Wypłacana kwota ustalana jest indywidualnie według prawa stanowego, na podstawie stażu służby i stopnia wojskowego weterana. Prawo określa także, przez jak długi okres świadczenie będzie wypłacane $^{90}$. W 2012 r. w ramach programu UCX wypłacono weteranom świadcze-

pracę), nie może być przekroczony okres 12 lat od momentu odejścia ze służby i określenia stopnia niepełnosprawności przez Departament Spraw Weteranów.

86 Transition to GPS, U.S. Department of Defense, https://www.dodtap.mil/transition_gps.html, dostęp 5.09.2015.

${ }_{87}$ E. Bass, H. Golding, Report: Veterans' Disability Compensation: Trends and Policy Options, Congressional Budget Office, August 2014, s. 9, http://www.cbo.gov/sites/default/files/113th-congress2013-2014/reports/45615-VADisability_2.pdf, dostęp 11.09.2015.

88 J.E. Stiglitz, L.J. Bilmes, Wojna za trzy biliony dolarów, Wydawnictwo Naukowe PWN, Warszawa 2010, s. 90.

89 Unemployment Compensation for Ex-Servicemembers (UCX): The Details, https://www.vets101. org/a/67/d1.aspx, dostęp 1.10.2015.

${ }_{90}$ Program UCX finansowany jest przez byłego zatrudniającego (np. wojska lądowe, marynarka wojenna), środki wypłacane są z funduszu operacyjnego. 
nia w wysokości 948 mln USD ${ }^{91}$. Uważa się, że ta forma pomocy może być jednym z powodów braku zaangażowania weteranów w poszukiwanie pracy, gdyż przez nawet 99 tygodni otrzymują oni świadczenie finansowe, które pozawala normalnie funkcjonować $c^{92}$. Mimo że przez wielu weteranów program UCX traktowany jest jako okres aklimatyzacji, adaptacji i przygotowania do życia w cywilu, to dla części weteranów stanowi czynnik zniechęcający do poszukiwania pracy. Dla weteranów pokolenia 9/11 dostępne są nowe możliwości, które nie były osiągalne wcześniej. Obecnie wszyscy weterani wojen w Iraku i Afganistanie otrzymują dzięki Departamentowi Spraw Weteranów (Department of Veterans Affairs) opiekę zdrowotną przez pięć lat od zakończenia służby, później natomiast mogą aplikować ponownie, aby podtrzymać to uprawnienie ${ }^{93}$. Ponadto, Departament Spraw Weteranów prowadzi specjalne centra dla Weteranów (Vet Centers). Utworzone po raz pierwszy w $1979 \mathrm{r} .^{94}$ (na potrzeby weteranów wojny w Wietnamie) punkty doradcze zlokalizowane są obecnie w kilku miastach i w każdym stanie oraz na terytorium Filipin, Puerto Rico, Wysp Dziewiczych, Guam i Samoa Amerykańskiego ${ }^{95}$. Centra prowadzą doradztwo i szkolenia w zakresie zatrudnienia, edukacji, świadczeń zdrowotnych.

Bezrobocie wśród weteranów pokolenia 9/11 staje się poważnym problemem w Stanach Zjednoczonych. Będzie on narastał w ciągu najbliższych lat, kiedy wojsko odczuje efekty sekwestracji, czyli automatycznego cięcia wydatków. W latach 2001-2014 młodzi weterani byli bardziej narażeni na bezrobocie niż ich cywilni rówieśnicy. Różnica ta jednak z biegiem czasu malała. Trafne jest zatem założenie, że wskaźnik bezrobocia wśród weteranów skorelowany jest z zaangażowaniem w poszukiwaniu pracy. Umiejętność skutecznego poszukiwania pracy dotyczy nie tylko weteranów, ale każdej osoby zdolnej do pracy i deklarującej chęć jej podjęcia. Biuro Statystyki Pracy podaje, że jeszcze w 2001 r. średni czas poszukiwania nowej pracy wynosił

${ }^{91}$ J.M. Whittaker, Unemployment Compensation (Insurance) and Military Service, Congressional Research Service Report, April 24, 2013, s. 2, https://www.fas.org/sgp/crs/misc/RS22440.pdf, dostęp 1.10.2015.

${ }_{92}$ M.C. Harrell, N. Berglass, Employing America's Veterans. Perspectives from Businesses, Center for a New American Security, June 2012, s. 28, http://benefits.va.gov/VOW/docs/EmployingAmericasVeterans.pdf, dostęp 11.09.2015.

93 Returning Servicemembers (OEF / OIF / OND), Enhanced Eligibility For Health Care, http://www. va.gov/healthbenefits/apply/returning_servicemembers.asp, dostęp 20.09.2015.

94 J. Humensky, N. Jordan, K. Strupe, D. Hynes, How Are Iraq/Afghanistan-Era Veterans Faring in the Labor Market?, "Armed Forces \& Society” 2013, Vol. 39, No. 1, s. 159, http://afs.sagepub.com/content/early/ 2012/06/15/0095327X12449433.full.pdf+html, dostęp 18.03.2015.

${ }^{95}$ Vet Centers Locations, U.S. Department of Veterans Affairs, http://www.va.gov/directory/guide/vetcenter.asp?isFlash=0, dostęp 20.09.2015. 
4,1 tygodnia, w 2011 r. wynosił już 10 tygodni ${ }^{96}$. Wyzwaniem jest jednak zarówno popyt, jak i podaż. Proste przygotowanie weteranów do wejścia na rynek pracy jest niewystarczające, osoby zatrudniające muszą dać szansę weteranom na wykazanie się swoimi umiejętnościami w pracy. Weterani mogą być dla zatrudniających cennym nabytkiem ze względu na umiejętności i doświadczenie, potrzebna jest jednak jeszcze większa współpraca sektora prywatnego i publicznego z weteranami, inicjatywa musi wychodzić z każdej ze stron.

Weterani to już w pewien sposób doświadczeni, wyselekcjonowani przez wojsko, najlepsi kandydaci do podjęcia pracy po zakończeniu służby. Dla większości Amerykanów służba wojskowa znalazła się poza ich zasięgiem. W 2012 r. mniej niż jeden na czterech kandydatów spełniał minimalne wymagania do podjęcia służby w wojsku ${ }^{97}$. Pentagon szacuje, że ponad 20\% uczniów nie kończy szkoły średniej, 35\% Amerykanów dyskwalifikuje otyłość, 19\% ma problemy z alkoholem lub narkotykami, 5\% ma kryminalną przeszłość ${ }^{98}$. W 2014 r. siedmiu na dziesięciu kandydatów w wieku 17-24 lata nie spełniało wymagań do podjęcia służby. Szacuje się, że do 2020 r. zaledwie dwóch na dziesięciu Amerykanów dostanie się do wojska ${ }^{99}$.

Niezmiernie istotnym elementem amerykańskiej gospodarki jest sukcesywne wspieranie weteranów i ich rodzin w procesie rekonwersji oraz ich ponowne włączenie do społeczeństwa. Ma to szczególne znaczenie w obliczu cięcia wydatków na obronność i redukcji stanów osobowych amerykańskiej armii po czternastoletnim zaangażowaniu w Iraku i Afganistanie. Efektywna współpraca, zatrudnienie i wsparcie edukacyjne stanowią podstawę sukcesu weteranów w ich dążeniu do powrotu na cywilny rynek pracy.

${ }^{96}$ R. Ilg, E. Theodossiou, Job search of the unemployed by duration of unemployment, Monthly Labor Review 133, No. 3 (March 2012), s. 43, http://www.bls.gov/opub/mlr/2012/03/art³full.pdf, dostęp 9.09.2015.

97 W 2012 r. wśród 31,1 mln młodych Amerykanów (17-24 lata), zaledwie 7,8 mln (23\%) spełniało minimalne standardy pozwalające na ubieganie się o przyjęcie do wojska. United States Army Recruiting Command, USAREC May 2013 Talking Points, s. 3, http://www.usarec.army.mil/hq/apa/download/May2013talking-points.pdf, dostęp 12.06.2015.

$98 \mathrm{~J}$. Rinaldi, Only one-in-four Americans fit to serve in the military, http://www.rt.com/usa/militaryservice-fit-american-449/, dostęp 22.09.2015.

99 C. Davis, Army Says Only 30\% of Americans Could Join, http://www.military.com/daily-news/ 2014/10/24/army-says-only-30-percent-of-americans-could-join.html, dostęp 22.09.2015. 


\section{Bibliografia}

Adams Ch., Millions went to war in Iraq, Afghanistan, leaving many with lifelong scars, http://www. mcclatchydc.com/news/nation-world/national/article24746680.html, dostęp 24.09.2015.

America's Heroes at Work - Veterans Hiring Toolkit, Top Ten Reasons to Hire Veterans and Wounded Warriors, U.S. Department of Labor, http://www.dol.gov/vets/ahaw/topten.htm, dostęp 1.09.2015.

Bass E., Golding H., Report: Veterans' Disability Compensation: Trends and Policy Options, Congressional Budget Office, August 2014, http://www.cbo.gov/sites/default/files/113th-congress-2013-2014/reports/45615-VADisability_2.pdf, dostęp 11.09.2015.

Berglass N., Harrell M.C., Well After Service. Veteran Reintegration and American Communities, Center for a New American Security, April 2012, http://www.cnas.org/files/documents/publications/CNAS_WellAfterService_BerglassHarrell.pdf, dostęp 18.07.2015.

Bezrobocie w USA najniższe od pięciu lat. W listopadzie spadło do 7 proc., http://m.wyborcza. biz/biznes/1,106501,15088744, Bezrobocie_w_USA_najnizsze_od_pieciu_lat_W_listopadzie.html?piano_t=1, dostęp 29.12.2014.

Boesler M., What The Unemployment And Labor Force Participation Rates Would Be If All Of The Discouraged Workers Came Back, http://www.businessinsider.com/unemploymentrate-if-discouraged-workers-came-back-2014-1, dostęp 22.09.2015.

Coile C., Duggan M., Guo A., Veterans' Labor Force Participation: What Role Does the VA's Disability Compensation Program Play?, "American Economic Review" 2015, Vol. 105, No. 5, American Economic Association.

Davis C., Army Says Only 30\% of Americans Could Join, http://www.military.com/daily-news/2014/10/24/army-says-only-30-percent-of-americans-could-join.html, dostęp 22.09.2015.

Daywalt T.L., Testimony given at House Committee on Veteran Affairs, Veterans Employment Summit, Washington, DC, September 13, 2011, https://veterans.house.gov/sites/republicans. veterans.house.gov/files/documents/VetJobs.pdf, dostęp 1.09.2015.

Deptuła T., USA: niełatwe powroty weteranów, http://www.ekonomia.rp.pl/artykul/1063797. html, dostęp 16.06.2015.

Difficult transitions, http://www.economist.com/blogs/democracyinamerica/2014/11/veterans-day, dostęp 5.09.2015.

Drummond K., Veterans Make Valuable Employees, So Why Aren't More Getting Hired? http:// www.forbes.com/sites/katiedrummond/2012/06/12/cnas-veterans-jobs/, dostęp 29.01.2015.

Employment Situation of Veterans Summary 2014, Bureau of Labor Statistics, U.S. Department of Labor, http://www.bls.gov/news.release/vet.nr0.htm, dostęp 22.09.2015.

Employment status of persons 18 years and over by veteran status, period of service, sex, race, and Hispanic or Latino ethnicity, 2014 annual averages, Bureau of Labor Statistics, U.S. Department of Labor, http://www.bls.gov/news.release/vet.t01.htm, dostęp 19.09.2015.

Enabling Collaborative Support to Reintegrate the Military Family, 2014, http://www.jcs.mil/Portals/36/Documents/CORe/141103_Enabling_Collaborative_Support.pdf, dostęp 5.09.2015. 
Gillespie P., Part-time jobs put millions in poverty or close to it, http://money.cnn.com/2014/11/ 20/news/economy/america-part-time-jobs-poverty/, dostęp 22.09.2015.

Gorman R., Saluting America's heroes: Obama joins sailors at end of emotional Veterans Day to watch college basketball spectacle on aircraft carrier that buried Bin Laden at sea, http:// www.dailymail.co.uk/news/article-2060426/Obama-marks-Veterans-Day-basketballspectacle-aircraft-carrier-buried-Bin-Laden-sea.html, dostęp 20.07.2015.

Hall K.C., Harrell M.C., Bicksler B., Stewart R., Fisher M.P., Veteran Employment. Lessons from the 100,000 Jobs Mission, RAND Corporation, 2014, http://www.rand.org/content/dam/rand/pubs/research_reports/RR800/RR836/RAND_RR836.pdf, dostęp 12.09.2015.

Harper J., Carter: Time to think about post-military career is while still serving, http://www.stripes. com/news/carter-time-to-think-about-post-military-career-is-while-still-serving-1.337836, dostęp 9.08.2015.

Harrell M.C., Berglass N., Employing America's Veterans. Perspectives from Businesses, Center for a New American Security, June 2012, http://benefits.va.gov/VOW/docs/EmployingAmericasVeterans.pdf, dostęp 11.09.2015.

Hipple S.F., The Labor Market in 2009: Recession Drags ON, "Monthly Labor Review" 2010, Vol. 133, No. 3, http://www.bls.gov/opub/mlr/2010/03/art1full.pdf, dostęp 1.09.2015.

Hobson J., Unemployment falls to 7.7\%, 236,000 jobs added, http://www.marketplace.org/topics/economy/unemployment-falls-77-236000-jobs-added, dostęp 5.12.2014.

How the Government Measures Unemployment, Current Population Survey (CPS), June 2014, Bureau of Labor Statistics, U.S. Department of Labor, http://www.bls.gov/cps/cps_htgm. pdf, dostęp 22.09.2015.

Humensky J., Jordan N., Strupe K., Hynes D., How Are Iraq/Afghanistan-Era Veterans Faring in the Labor Market?, Armed Forces \& Society 39 (I), 2013, http://afs.sagepub.com/content/early/2012/06/15/0095327X12449433.full.pdf+html, dostęp 18.03.2015.

Ilg R., Theodossiou E., Job search of the unemployed by duration of unemployment, "Monthly Labor Review" 2012, Vol. 133, No. 3, http://www.bls.gov/opub/mlr/2012/03/art ${ }^{3}$ full.pdf, dostęp 9.09.2015.

Irak. Dylematy amerykańskiej interwencji, red. W. Dzielski, W. Michnik, Księgarnia Akademicka, Kraków 2007.

Jager E., Petraeus: Returning Veterans Deserve More than 'Dead-End Jobs', http://www.newsmax. com/US/veterans-petraeus-goodfriend-jobs/2014/01/22/id/548294/, dostęp 15.07.2015.

Jones J., Goldberg D., Put veterans to work, http://www.latimes.com/opinion/op-ed/la-oe-jones-employ-veterans-20131111-story.html\#axzz²kROfV4nY, dostęp 14.01.2015.

Kleykamp M., Unemployment, Earnings and Enrollment among Post 9/11 Veterans, "Social Science Research" 2013, No. 42, http://www.sciencedirect.com/science/article/pii/S0049089X1 3000021 , dostęp 17.06.2015.

Kozłowski S.G., Ameryka współczesna. Pejzaż polityczny i społeczno-gospodarczy, Wydawnictwa UMCS, Lublin 2008.

Lindsey E., 2013 State of the Union Address: An annotated transcript, http://www.marketplace. org/topics/economy/2013-state-union-address-annotated-transcript, dostęp 11.02.2014. 
Litan R., Why Do Young Veterans Have So Much Trouble Finding Jobs? http://blogs.wsj.com/washwire/2014/10/01/why-do-young-veterans-have-so-much-trouble-finding-jobs/, dostęp 19.01.2015.

Loughran D.S., Why Is Veteran Unemployment So High? RAND Corporation, Santa Monica 2014, http://www.rand.org/content/dam/rand/pubs/research_reports/RR200/RR284/RAND_ RR284.pdf, dostęp 9.09.2015.

Loughran D.S., Martorell P., Miller T., Klerman J.A., The Effect of Military Enlistment on Earnings and Education, RAND Corporation, Santa Monica 2011, http://www.rand.org/content/ dam/rand/pubs/technical_reports/2011/RAND_TR995.pdf, dostęp 9.09.2015.

Lucas F., Why Is the Jobless Rate for Iraq and Afghanistan Veterans so High? http://www.theblaze. com/stories/2013/10/25/why-is-the-jobless-rate-for-iraq-and-afghanistan-veterans-sohigh/, dostęp 20.12.2014.

Michałek K., Amerykańskie stulecie. Historia Stanów Zjednoczonych Ameryki 1900-2001, MADA, Warszawa 2004.

Palowski J., Zwolnienia żołnierzy w US Army. Szczegóły planu cięć, http://www.defence24. pl/238133, zwolnienia-zolnierzy-w-us-army-szczegoly-planu-ciec, dostęp 21.06.2015.

Rein L., Record numbers of veterans are getting jobs in the government - but a lot of them quit, http://www.washingtonpost.com/blogs/federal-eye/wp/2015/08/28/record-numbers-ofveterans-are-getting-jobs-in-the-government-but-a-lot-of-them-arent-staying/, dostęp 12.09.2015.

Returning Servicemembers (OEF/OIF/OND), Enhanced Eligibility For Health Care, http://www. va.gov/healthbenefits/apply/returning_servicemembers.asp, dostęp 20.09.2015.

Rinaldi J., Only one-in-four Americans fit to serve in the military, http://www.rt.com/usa/military-service-fit-american-449/, dostęp 22.09.2015.

Schneider A., Iraq and Afghanistan War Veterans Still Battling Unemployment, http://www.houstonpublicmedia.org/news/iraq-and-afghanistan-war-veterans-still-battling-higherthanaverageunemployment/, dostęp 16.02.2015.

Schneider A., Iraq and Afghanistan War Veterans Still Battling Unemployment, http://www.houstonpublicmedia.org/news/iraq-and-afghanistan-war-veterans-still-battling-higherthanaverageunemployment/, dostęp 16.02.2015.

Schultz J., State help for returning veterans, National Conference of State Legislatures, http:// www.ncsl.org/research/military-and-veterans-affairs/state-help-for-returning-veterans. aspx, dostęp 12.09.2015.

Segal D., Recruiting for Uncle Sam: Citizenship and Military Manpower Policy, University Press of Kansas, Lawrence 1989.

Smith-Barrow D., For Veterans to Prosper in STEM Workforce, Employers Need to Help With Post-Military Transition, http://www.usnews.com/news/stem-solutions/articles/2015/06/30/forveterans-to-prosper-in-stem-workforce-employers-need-to-help-with-post-militarytransition, dostęp 15.08.2015.

Stiglitz J.E., Bilmes L.J., Wojna za trzy biliony dolarów, Wydawnictwo Naukowe PWN, Warszawa 2010. 
Szymendera S.D., Who is a „Veteran”? - Basic Eligibility for Veterans' Benefits, Congressional Research Service Report, August 19, 2015, https://www.fas.org/sgp/crs/misc/R42324.pdf, dostęp 24.02.2014.

Trudny problem: weterani, http://www.dziennik.com/publicystyka/artykul/trudny-problem-weterani, dostęp 20.04.2015.

U.S. Equal Employment Opportunity Commission, Veterans and the Americans with Disabilities Act (ADA): A Guide for Employers, http://www.eeoc.gov/eeoc/publications/ada_veterans_employers.cfm, dostęp 18.09.2015.

Unemployment Compensation for Ex-Servicemembers (UCX): The Details, https://www.vets101. org/a/67/d1.aspx, dostęp 1.10.2015.

USERRA Advisor, U.S. Department of Labor, http://www.dol.gov/elaws/vets/userra/userra. asp, dostęp 18.09.2015.

Veteran unemployment rate decreases to 5.3 percent in 2014, http://www.bls.gov/opub/ted/2015/veteran-unemployment-decreases-in-2014.htm, dostęp 6.08.2015.

Veterans: What next? http://www.economist.com/news/united-states/21635478-nearly-halfnew-federal-employees-are-military-veterans-what-next, dostęp 12.03.2015.

Wałkuski M., Wałkowanie Ameryki, Wydawnictwo Helion, Gliwice 2012.

Whittaker J.M., Unemployment Compensation (Insurance) and Military Service, Congressional Research Service Report, April 24, 2013, https://www.fas.org/sgp/crs/misc/RS22440.pdf, dostęp 1.10.2015.

Wróbel T., Znikająca armia, „Polska Zbrojna” 2015, nr 8.

Wyler G., Here's The Full Text Of Tonight's State Of The Union Address, http://www.businessinsider.com/full-text-barack-obama-state-of-the-union-2012-1, dostęp 12.01.2014. 